Provided for non-commercial research and education use. Not for reproduction, distribution or commercial use.

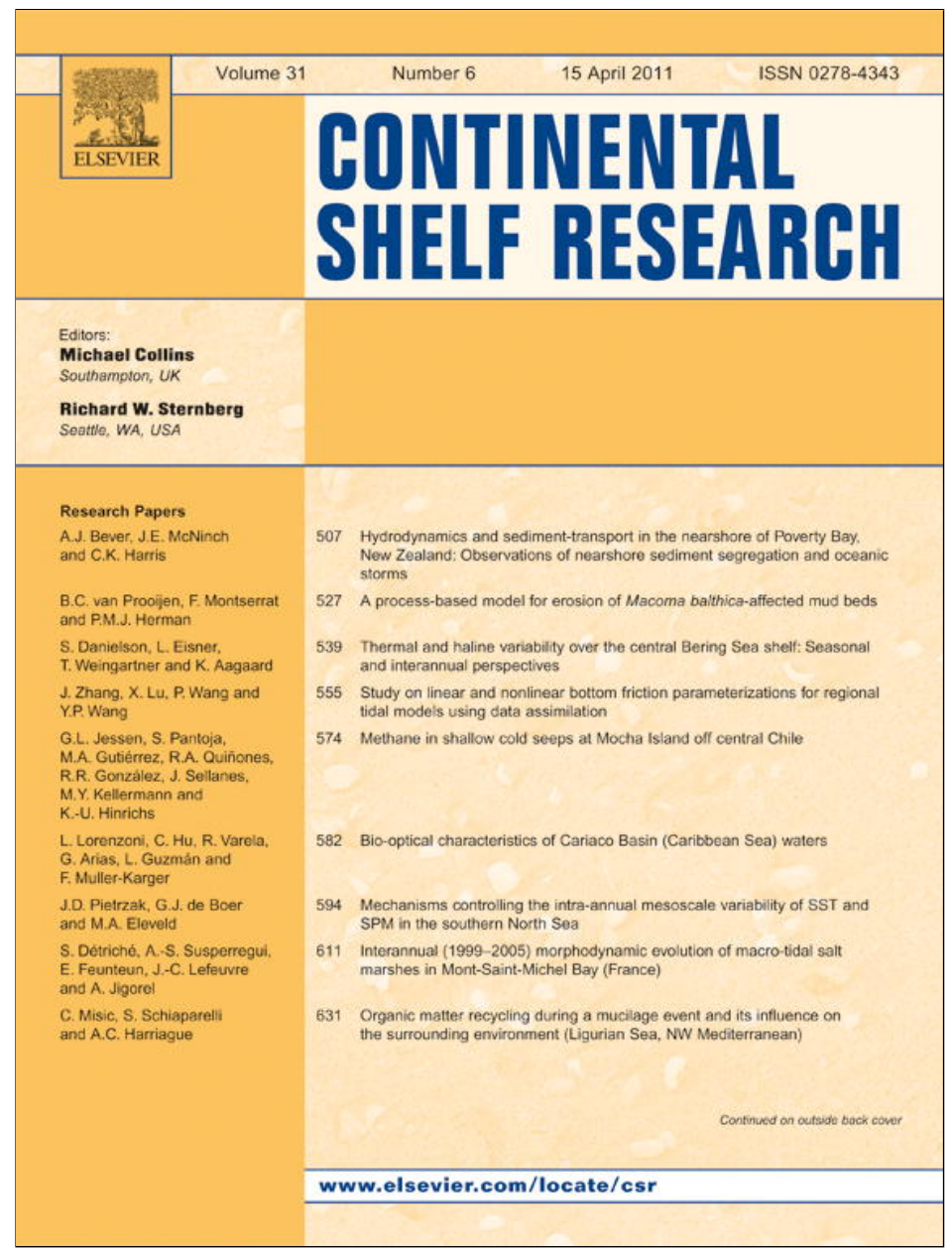

This article appeared in a journal published by Elsevier. The attached copy is furnished to the author for internal non-commercial research and education use, including for instruction at the authors institution and sharing with colleagues.

Other uses, including reproduction and distribution, or selling or licensing copies, or posting to personal, institutional or third party websites are prohibited.

In most cases authors are permitted to post their version of the article (e.g. in Word or Tex form) to their personal website or institutional repository. Authors requiring further information regarding Elsevier's archiving and manuscript policies are encouraged to visit:

http://www.elsevier.com/copyright 
Research papers

\title{
Benthic remineralization in the northwest European continental margin (northern Bay of Biscay)
}

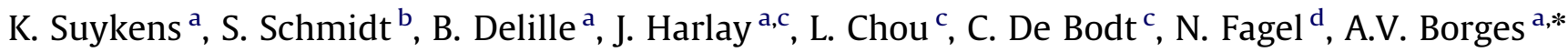 \\ a Unité d'Océanographie Chimique, Université de Liège, Belgium \\ b Environnements et Paléoenvironnements Océaniques, CNRS-Université Bordeaux 1, France \\ ' Laboratoire d'Océanographie Chimique et Géochimie des Eaux, Université Libre de Bruxelles, Belgium \\ ${ }^{\mathrm{d}}$ Laboratoire des Argiles, Géochimie et Environnement Sédimentaires, Université de Liège, Belgium
}

\section{A R T I C L E I N F O}

\section{Article history:}

Received 3 February 2010

Received in revised form

23 November 2010

Accepted 24 December 2010

Available online 20 January 2011

\section{Keywords:}

Continental shelf

Benthic organic carbon degradation

$\mathrm{CaCO}_{3}$ dissolution

Benthic silica fluxes

Benthic $\mathrm{NO}_{3}$ fluxes

\begin{abstract}
A B S T R A C T
We report a dataset of sediment characteristics and biogeochemical fluxes at the water-sediment interface at the northwest European continental margin (northern Bay of Biscay). Cores were obtained in June 2006, May 2007 and 2008, at 18 stations on the shelf break (120-180 m), and at 2 stations on the continental slope (520 and $680 \mathrm{~m}$ ). Water-sediment fluxes of dissolved oxygen $\left(\mathrm{O}_{2}\right)$, total alkalinity (TA), nitrate $\left(\mathrm{NO}_{3}^{-}\right)$, and dissolved silicate (DSi) were measured at a total of 20 stations. Sediment characteristics include: grain size, chlorophyll- $a(\mathrm{Chl}-a)$ and phaeopigment (Phaeo) content, particulate organic (POC) and inorganic (PIC) carbon content, and lead-210 $\left({ }^{210} \mathrm{~Pb}\right)$ and thorium-234 $\left({ }^{234} \mathrm{Th}\right)$ activities. Sediments were sandy (fine to coarse) with organic matter (OM) (1.0-4.0\%) and Chl- $a(0.01-$ $0.95 \mu \mathrm{g} \mathrm{g}^{-1}$ ) contents comparable to previous investigations in the same region, and a relatively high PIC fraction (0.8-10.2\%). Water-sediment $\mathrm{O}_{2}$ fluxes $\left(-2.4\right.$ to $-8.4 \mathrm{mmol} \mathrm{O}_{2} \mathrm{~m}^{-2} \mathrm{~d}^{-1}$ ) were low compared to other coastal environments and correlated well with OM and Chl- $a$ content. ${ }^{234}$ Th activity profiles indicated that Chl- $a$ sediment content was mainly controlled by physical mixing processes related to local hydrodynamics. The correlation between water-sediment fluxes of $\mathrm{O}_{2}$ and $\mathrm{NO}_{3}^{-}$ indicated a close coupling of nitrification/denitrification and total benthic organic carbon degradation. Dissolution of biogenic silica $\left(0.05-0.95 \mathrm{mmol} \mathrm{m} \mathrm{m}^{-2} \mathrm{~d}^{-1}\right)$ seemed uncoupled from organic carbon degradation, as characterized by water-sediment $\mathrm{O}_{2}$ fluxes. The link between water-sediment fluxes of TA and $\mathrm{O}_{2}$ indicated the occurrence of metabolic driven dissolution of calcium carbonates $\left(\mathrm{CaCO}_{3}\right)$ in the sediments $\left(\sim 0.33 \pm 0.47 \mathrm{mmol} \mathrm{m}^{-2} \mathrm{~d}^{-1}\right)$, which represented $\sim 1 \%$ of the pelagic calcification rates due to coccolithophores measured during the cruises. These $\mathrm{CaCO}_{3}$ dissolution rates were below those reported in sediments of continental slopes and of the deep ocean, probably due to the high oversaturation with respect to $\mathrm{CaCO}_{3}$ of the water column overlying the continental shelf sediments of the northern Bay of Biscay. Rates of total benthic organic carbon degradation were low compared to water column rates of primary production and aphotic community respiration obtained during the cruises.
\end{abstract}

(c) 2011 Elsevier Ltd. All rights reserved.

\section{Introduction}

Understanding the controls on carbon (C) remineralization and burial in continental margin sediments is relevant for the description of the global $\mathrm{C}$ cycle. While continental margins only represent $\sim 20 \%$ of the total seafloor, they contain $\sim 50-60 \%$ of the total sediment volume (Burdige, 2006). In addition, shallow carbonates deposited in reefs, banks, bays and shelves account for $33 \%$ of the oceanic calcium carbonate $\left(\mathrm{CaCO}_{3}\right)$ production and about 38\% of oceanic $\mathrm{CaCO}_{3}$ accumulation (Milliman, 1993).

Carbon is drawn down from the surface ocean by the reduction of dissolved inorganic carbon (DIC) to particulate organic carbon

\footnotetext{
* Corresponding author. Tel.: +3243663187.

E-mail address: alberto.borges@ulg.ac.be (A.V. Borges).
}

(POC) through photosynthesis, and by the precipitation of $\mathrm{CaCO}_{3}$ by pelagic calcifiers and reef-building organisms. Much of the organic carbon (OC) is rapidly converted back to carbon dioxide $\left(\mathrm{CO}_{2}\right)$ in the water column as a result of heterotrophic oxidation. Only a small proportion of OC reaches the sea floor, and is buried and preserved. The burial of $\mathrm{OC}$ in marine sediments represents the major link between "active" surface pools of $C$ in the oceans, in the atmosphere, on land, and in marine sediments, and $\mathrm{C}$ pools that cycle on much longer, geological time scales, i.e., $\mathrm{C}$ in sedimentary rocks, and petroleum deposits (Burdige, 2006).

In aphotic sediments, the $C$ added to the water-sediment interface in the form of organic matter $(\mathrm{OM})$ can be approximated by the Redfield stoichiometry $\left(\mathrm{CH}_{2} \mathrm{O}\right)_{106}\left(\mathrm{NH}_{3}\right)_{16} \mathrm{H}_{3} \mathrm{PO}_{4}$ (Redfield et al., 1963) and is largely remineralized by bacterial metabolism. The timing, amount and freshness of the OM delivered to the sediments have important consequences for the structure of 
benthic communities (e.g., Heip et al., 2001) and the geochemistry of the sediment (e.g., Berner, 1980). This, in turn, affects the timing and magnitude of sedimentary nutrient fluxes and oxygen $\left(\mathrm{O}_{2}\right)$ demand (e.g., Soetaert et al., 1996). The occurrence of specific respiratory processes is controlled by the free energy yield per mole of OC oxidized by each of the electron acceptors (Froelich et al., 1979). Oxidation of OM by $\mathrm{O}_{2}$ (Eq. (1)) is the most efficient respiratory process in terms of energy acquired per mole of $\mathrm{C}$ oxidized. The microbially mediated oxidation of $\mathrm{OM}$ by $\mathrm{O}_{2}$, which takes place in the uppermost layer of the sediments, also promotes the dissolution of $\mathrm{CaCO}_{3}$ (Froelich et al., 1979; Cai et al., 1995; Jahnke et al., 1997; Jahnke and Jahnke, 2000)

$\mathrm{CH}_{2} \mathrm{O}+\mathrm{O}_{2} \rightarrow \mathrm{CO}_{2}+\mathrm{H}_{2} \mathrm{O}$

$\mathrm{CaCO}_{3}+\mathrm{CO}_{2}+\mathrm{H}_{2} \mathrm{O} \rightarrow \mathrm{Ca}^{2+}+2 \mathrm{HCO}_{3}^{-}$

In addition, suboxic and anoxic remineralization are important processes at continental margins (Burdige, 2006). The oxidation of $\mathrm{OM}$ by nitrate $\left(\mathrm{NO}_{3}^{-}\right.$, denitrification) produces protons and also promotes the dissolution of $\mathrm{CaCO}_{3}$. In contrast, the oxidation of $\mathrm{Mn}^{2+}, \mathrm{Fe}^{2+}$ and $\mathrm{SO}_{4}^{2-}$ reduces protons (and hence produces total alkalinity (TA)) and may induce the precipitation of $\mathrm{CaCO}_{3}$ (Boudreau et al., 1992).

In mixed oxic and anoxic sediments, aerobic respiration and denitrification are the most efficient redox reactions to degrade OM. Due to bioturbation, bioirrigation and molecular diffusion, internal redox cycling reactions couple aerobic chemolithotrophic reactions with aerobic respiration, such that there is no net loss of reduced intermediates during the redox cycling. Hence, $\mathrm{O}_{2}$ appears to be the main oxidant of $\mathrm{OM}$, and $\mathrm{O}_{2}$ fluxes provide a reasonable good estimate of the overall rate of sediment $\mathrm{OM}$ oxidation, even though aerobic respiration is a variable fraction of the total diagenetic $C$ degradation (Burdige, 2006).

Sandy sediments cover about $70 \%$ of continental shelves and are often thought to be poor in $\mathrm{OM}$ and other reactive substances (Boudreau et al., 2001). However, water flow through sands converts these sediments into effective filter systems (Boudreau et al., 2001) transporting suspended particles, algae and bacteria into the sediments. The studies by Boudreau et al. (2001) and Rusch et al. (2006) show that, in most sandy shelf sediments, OM has a higher average degradability than in most finer-grained sediments, since the freshly produced $\mathrm{OC}$ in sands is not diluted by accumulating aged material.

The objective of this study is to evaluate diagenetic OM degradation and $\mathrm{CaCO}_{3}$ dissolution in sediments. We sampled surface sediments, at depths between 124 and $680 \mathrm{~m}$, during three cruises in June 2006, May 2007 and 2008 along the shelf break of the northwest European continental margin (northern Bay of Biscay). We present a dataset of sediment characteristics (grain size, chlorophyll- $a$ (Chl- $a$ ) and phaeopigment (Phaeo) contents, POC and PIC content, and lead-210 $\left({ }^{210} \mathrm{~Pb}\right)$ and thorium-234 $\left({ }^{234} \mathrm{Th}\right)$ activities) and of biogeochemical water-sediment fluxes $\left(\mathrm{O}_{2}, \mathrm{TA}\right.$, $\mathrm{NO}_{3}^{-}$, and dissolved silicate (DSi)). Such a combination of sediment characteristics and of fluxes at the water-sediment interface contributes to estimate a $C$ budget of sandy sediments of the northern Bay of Biscay in late-spring early-summer.

\section{Materials and methods}

\subsection{Site description}

The continental margin in the northern Bay of Biscay is characterized by a broad continental shelf (the Celtic Sea) and delineated westward by a steep slope down to $4000 \mathrm{~m}$ depth, heavily indented with canyons (Fig. 1). Current measurements along the NW European continental margin show that a persistent

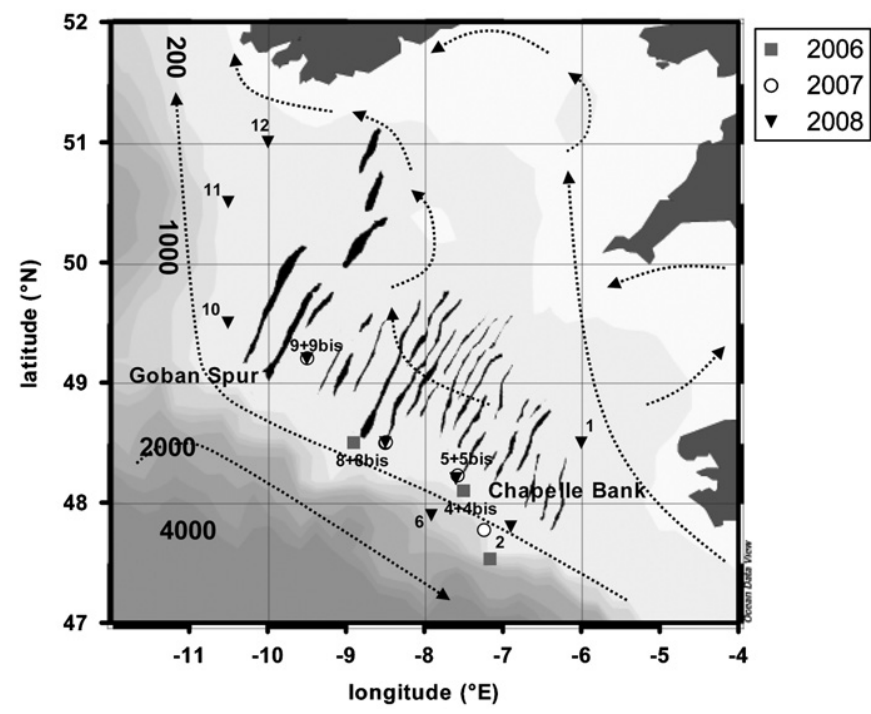

Fig. 1. Map showing the sampling stations in the northern Bay of Biscay in June 2006 (gray square), May 2007 (open circle) and May 2008 (black triangle down), the 200,100, 2000 and $4000 \mathrm{~m}$ isobaths, seabed sand banks (Zaragosi et al., 2001) and the general residual surface circulation (dotted arrows) based on Pingree and Le Cann $(1989,1990)$ and Hutnance et al. (2001).

northward flowing current dominates the upper slope between the La Chapelle Bank and the Goban Spur areas (Pingree and Le Cann, 1989). During spring and summer, the turbulent dissipation of internal tides at the shelf break leads to the deepening of the thermocline and mixing of surface waters and deeper waters. Enhanced vertical mixing and upwelling of cold nutrient-rich deep seawater locally induces enhanced primary production at the shelf edge, which is intense to the southeast (La Chapelle Bank), where the slope becomes steeper (Pingree and Le Cann, 1989; Pingree and New, 1995; Wollast and Chou, 2001; Sharples et al., 2007; 2009; Harlay et al., 2010, in press). In this area, recurrent and frequent blooms of the coccolithophore Emiliania huxleyi are observed (Holligan et al., 1993; Garcia-Soto et al., 1995; Wollast and Chou, 2001; Godoi et al., 2009; Harlay et al., 2009, 2010, in press; Suykens et al., 2010). E. huxleyi blooms promote export of $\mathrm{C}$ to depth on relatively short time scales through calcification and related ballast effect, and through the formation of transparent exopolymer particles (TEP) that promote aggregate formation (Alldredge et al., 1993; De La Rocha and Passow, 2007).

Near-bed currents measured on the upper slope are directed off-slope and are stronger in autumn/winter than during spring/ summer, nevertheless they are still sufficiently high $\left(8.5 \mathrm{~cm} \mathrm{~s}^{-1}\right.$ at 247 and $600 \mathrm{~m}$ depth over the Goban Spur (Thomsen and van Weering, 1998) to be capable of re-suspension of phytodetritus in the benthic boundary layer (BBL) and induce downslope transport (Lampitt, 1985; van Weering et al., 2001). These re-suspension events increase the residence time of particles in the water column, during which $C$ reactivity decreases (Walsh, 1991). Bottom water currents predominantly transport re-suspended material along slope (NNW flow) with a minor offshore mixing component along isopycnal surfaces (Pingree et al., 1999). Aggregate formation in the $\mathrm{BBL}$ is considered the dominant process controlling particle accumulation. The organic fraction has low settling velocities, ranging from 132 to $200 \mathrm{~m} \mathrm{~d}^{-1}$ (Herman et al., 2001), and high residence times within the BBL (van Weering et al., 2001).

Large tidal sand dunes (Carruthers, 1963) and wave ripples (Leckie, 1988) are observed on the sand bank inward of the $200 \mathrm{~m}$ isobath (Fig. 1). Reynaud et al. (1999) suggested that these features are sustained by fine sand transport and deposition in the Celtic Sea, where the finest grain sizes have been put in suspension 
during reworking events under the combined effect of waves and tidal currents, and have partly settled down during motionless stages during neap tides and fair weather. This explains the coexistence of coarse-grained wave ripples and fine-grained sand patches in the upper bank area (Channon and Hamilton, 1976).

\subsection{Cruises}

Three cruises were carried out in the northern Bay of Biscay from 31/05/2006 to $09 / 06 / 2006$ (BG06/11 cruise), 10/05/2007 to $24 / 05 / 2007$ (BG07/12 cruise), and 07/05/2008 to $23 / 05 / 2008$ (BG08/12 cruise). Due to shorter ship-time, sampling during the June 2006 cruise was limited to the area around the La Chapelle Bank, while during the other two cruises sampling was also carried out further north along the continental margin (Fig. 1). Sampling was mainly concentrated on the continental shelf edge; only 2 stations (stations 2 (2006) and 6 (2008)) were carried out on the continental slope (Table 1 ).

\subsection{Water column sampling}

Sampling of bottom water was carried out with a rosette of 12 Niskin bottles $(12 \mathrm{~L})$ coupled to a Conductivity-TemperatureDepth probe (Seabird SBE21). Water column TA, Chl-a, Phaeo and $\mathrm{O}_{2}$ measurements were carried out as described below. $\mathrm{pH}$ was measured with a combined electrode (METROHM 6.0232.100) calibrated on the total hydrogen ion concentration scale using TRIS (2-amino-2-hydroxymethyl-1,3-propanediol) and AMP (2aminopyridine) buffers prepared at a salinity of 35 according to Dickson (1993). The saturation state of calcite $\left(\Omega_{\mathrm{CAL}}\right)$ was computed from $\mathrm{pH}$ and TA using the carbonic acid dissociation constants of Mehrbach et al. (1973) as refitted by Dickson and Millero (1987), the calcite solubility of Mucci (1983), and the $\mathrm{Ca}^{2+}$ concentration calculated from salinity using the ratio given by Riley and Tongudai (1967), following the recommendations of Lewis and Wallace (1998) and Dickson et al. (2007). Nitrate+ nitrite $\left(\mathrm{NO}_{X}\right)$ concentrations were determined colorimetrically with a Technicon Autoanalyzer system, on $20 \mathrm{~mL}$ samples, using the method described by Grasshoff et al. (1983). DSi was determined on $20 \mathrm{~mL}$ samples using the colorimetric method described by Grasshoff et al. (1983) on a Skalar automatic analyzer.

Suspended particulate matter (SPM) concentration was determined on $2 \mathrm{~L}$ samples filtered onto a pre-weight Nuclepore membrane $(0.4 \mu \mathrm{m}, \varnothing=47 \mathrm{~mm})$ and then rinsed 3 times with an isotonic solution to remove the salt. The filter was placed in a Petri dish and kept at $-20^{\circ} \mathrm{C}$ until analysis. Prior to the analysis, filters were dried at $50{ }^{\circ} \mathrm{C}$ overnight and kept at room temperature in a desiccator. The weight of particles retained on the membrane was determined by subtracting the weight of the filter before and after filtration. For the particulate $C$ analysis, $250 \mathrm{~mL}$ of seawater was filtered in duplicate on pre-combusted $(4 \mathrm{~h}$, $\left.500{ }^{\circ} \mathrm{C}\right) 25 \mathrm{~mm} \mathrm{GF} / \mathrm{F}$ filters. Filters retaining the particulate matter were stored at $-20{ }^{\circ} \mathrm{C}$ until elemental analysis with a Fisons NA-1500. Within three months of the cruise, filters were dried overnight at $50{ }^{\circ} \mathrm{C}$. Total particulate carbon (TPC) content was measured on the filters by elemental analysis. For the determination of $\mathrm{POC}, \mathrm{CaCO}_{3}$ particles were first removed by overnight exposure to strong acid fumes and then analyzed for the $\mathrm{C}$ content. PIC was determined by subtracting POC from TPC. Calibration of the analyzer was performed using certified reference stream sediment (STSD-2) from the Geological Survey of Canada. Samples for Chl- $a$ determination were obtained by filtering $250 \mathrm{~mL}$ of seawater on $47 \mathrm{~mm} \mathrm{GF} / \mathrm{F}$ filters and were stored at $-20{ }^{\circ} \mathrm{C}$ until analysis by fluorimetry.

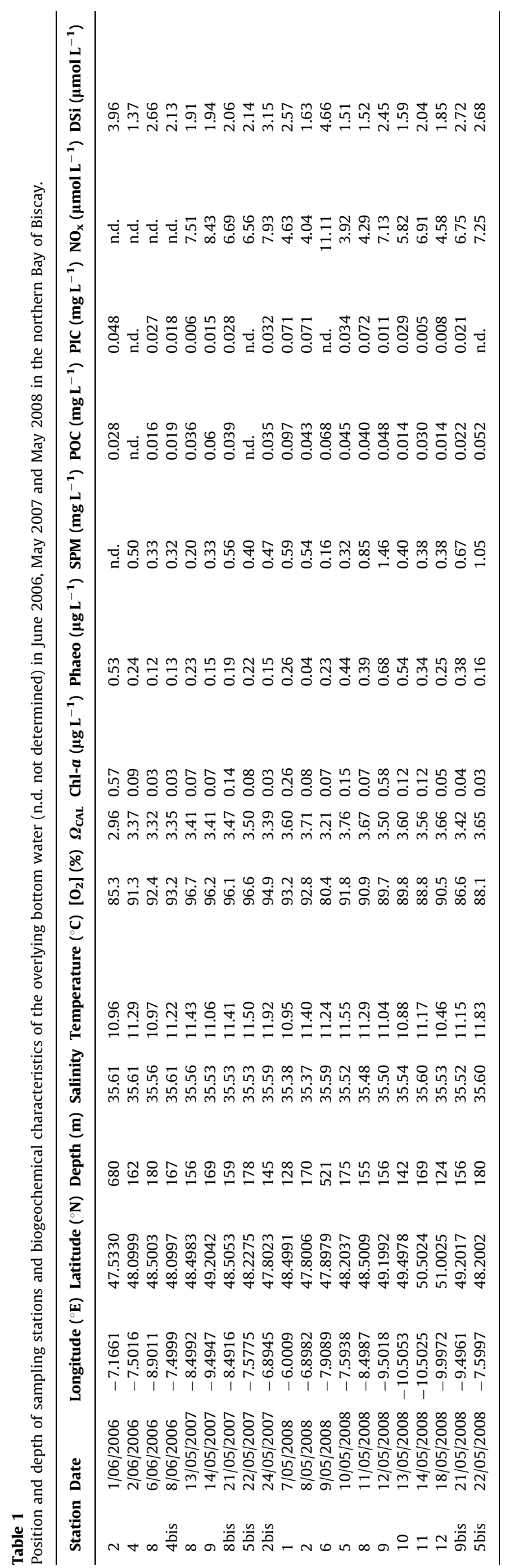




\subsection{Sediment core sampling and incubations}

Twenty undisturbed sediment box cores were collected for onboard incubations during the 3 cruises at 20 stations on the continental shelf and the upper slope of the La Chapelle Bank and on the continental shelf of the Goban Spur (Fig. 1; Table 1). Some stations were visited each year. Four cores were sub-sampled in $50 \mathrm{~cm}$ long Plexiglas tubes, with an internal diameter of $8 \mathrm{~cm}$, from each box core, as soon as the box core was on deck. The average core length was $14.5 \mathrm{~cm}$, ranging between 8.0 and $20.0 \mathrm{~cm}$. The overlying water was kept in the tube to avoid disturbance of the sediment interface. When necessary, bottom water, sampled with a Niskin bottle at the same station, was added to completely fill the tube. Average water volume inside the tubes was $1.6 \pm 0.3 \mathrm{dm}^{3}$. A $5 \mathrm{~cm}$ Teflon-coated magnetic stirring bar was inserted into the tubes at $\sim 5 \mathrm{~cm}$ above the water-sediment interface to stir the incubated water, and a Polyvinyl chloride stopper was used to avoid gas exchange with the atmosphere. The cores were kept in the dark and thermostated at $11^{\circ} \mathrm{C}$, close to the temperature of bottom waters overlying the sediments (Table 1 ). The overall procedure between the arrival of the box core on deck and the start of the incubations $\left(T_{0}\right)$ lasted about $45 \mathrm{~min} . \mathrm{O}_{2}$, TA, DSi and $\mathrm{NO}_{3}^{-}$were sampled with plastic syringes at $T_{0}$ and at the end of the incubation $\left(T_{1}\right)$, and transferred in glass or plastic containers. At either $T_{0}$ or $T_{1}$, the total sampled volume for all analysis was $\sim 170 \mathrm{~mL}$. $T_{1}$ was sampled after $24 \mathrm{~h}$ during the incubations in 2006. In 2007 and 2008, the incubation time was increased to $42 \mathrm{~h}$, to increase the sensitivity of concentration differences of all quantities, by using a second incubation set, allowing the incubation of two stations (8 cores in total) in parallel. Samples for $\mathrm{O}_{2}$ were fixed immediately after collection and analyzed within $24 \mathrm{~h} ; \mathrm{TA}, \mathrm{NO}_{3}^{-}$and DSi samples were filtered through $0.2 \mu \mathrm{m}$ polycarbonate membrane filters and stored at ambient temperature, -20 and $4{ }^{\circ} \mathrm{C}$, respectively. At the end of the incubations, two cores were sampled for PIC, POC, Chl- $a$ and Phaeo in the top $5 \mathrm{~cm}$ with an interval of $1 \mathrm{~cm}$. Samples for POC and PIC were dried onboard and stored in $50 \mathrm{~mL}$ plastic containers, and samples for Chl- $a$ and Phaeo determination ( $\sim 2 \mathrm{~cm}^{3}$ of sediment) were stored in glass containers at $-20^{\circ} \mathrm{C}$. One core was used as a whole for the granulometric analysis and was kept at ambient temperature in a closed bucket. During the 2007 and 2008 cruises, the fourth core was extruded for ${ }^{234} \mathrm{Th}$ and ${ }^{210} \mathrm{~Pb}$ determination in sediments taken at a resolution of $1 \mathrm{~cm}$ interval along the whole core; the samples were stored at $4{ }^{\circ} \mathrm{C}$. An aliquot of sediment was sub-sampled during the last three stations of the 2008 cruise at the water-sediment interface with a plastic syringe for TEP determination. The water-sediment fluxes of $\mathrm{O}_{2}\left(\mathrm{FO}_{2}\right), \mathrm{TA}$ (FTA), DSi (FDSi) and $\mathrm{NO}_{3}^{-}\left(\mathrm{FNO}_{3}^{-}\right)$were computed from the changes in concentration between $T_{0}$ and $T_{1}$, and expressed per surface unit. A negative flux corresponds to an uptake of the solute by the sediments from the overlying water, and a positive flux corresponds to a release of the solute from the sediment to the overlying water.

To reduce the total sampled volume at $T_{0}$ and $T_{1}$, samples for $\mathrm{O}_{2}$, TA, DSi and $\mathrm{NO}_{3}^{-}$were not duplicated on each core, although at each station incubations were performed on 4 cores to allow the representation of flux heterogeneity related to small scale spatial variability. The precisions of analysis given hereafter are based on replication of measurements in the water column samples based on the same analytical techniques.

The dissolved $\mathrm{O}_{2}$ concentration was measured on $60 \mathrm{~mL}$ biological oxygen demand bottles with an automated Winkler titration technique using a potentiometric endpoint determination, with an average precision of $\pm 0.6 \mu \mathrm{mol} \mathrm{L}^{-1}$. Reagents and standardizations were similar to those described by Knap et al. (1996). Measurements of TA were carried out by potentiometric titration with $\mathrm{HCl} 0.1 \mathrm{M}$ on $50 \mathrm{~mL}$ samples and endpoint determination according to Gran (1952) with an average precision of $\pm 4.0 \mu \mathrm{mol} \mathrm{L}^{-1}$, and data were quality checked with certified reference material acquired from Andrew Dickson (Scripps Institution of Oceanography, University of California, San Diego). DSi concentrations were measured as described above with an average precision $\pm 0.3 \mu \mathrm{mol} \mathrm{L}^{-1}$. The analysis of $\mathrm{NO}_{3}^{-}$was carried out as described above, with an average precision of $\pm 0.6 \mu \mathrm{mol} \mathrm{L}^{-1}$.

The concentrations of Chl- $a$ and Phaeo were quantified fluorimetrically following Yentsch and Menzel (1963) after extraction overnight at $4{ }^{\circ} \mathrm{C}$ in the dark in $90 \%$ acetone; after analysis, the sediments were dried and weighted. Granulometric analysis was performed by wet sieving over 2000,500, 250, 125 and $63 \mu \mathrm{m}$ sieves. After an initial drying of a sediment sample (approximately $30 \mathrm{~g}$ ) for $48 \mathrm{~h}$ at $60{ }^{\circ} \mathrm{C}$, the percentage of OM was estimated by loss

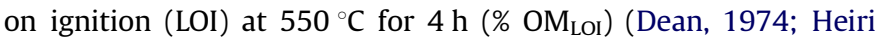
et al., 2001) with a precision from $\pm 0.01 \%$ to $\pm 0.20 \%$. This method ignites all OM and is traditionally converted to \% POC using a conversion factor ranging from 1.7 to 2.2 as reported in soil literature (Sutherland, 1998). However a fixed conversion factor is not always appropriate because it changes with the nature of OM in the sediments (Howard and Howard, 1990; Sutherland, 1998; Santisteban et al., 2004) and with the grain size (Sutherland, 1998). The conversion factor was computed by comparing the \% $\mathrm{OM}_{\mathrm{LO}}$ to the \% POC analysis of the same samples by elemental analysis (\% $\mathrm{POC}_{\mathrm{EA}}$ ) with a Fisons NA-1500 on $50 \mathrm{mg}$ samples as described above for water column POC measurements. As the \% $\mathrm{OM}_{\mathrm{LOI}} \%$ $\mathrm{POC}_{\mathrm{EA}}$ ratios were not well correlated to median grain size $\left(r^{2}=0.13\right.$, not shown), we were not able to deduce an appropriate conversion factor. Therefore, we chose not to convert OM to POC content, and hereafter we use and discuss the $\% \mathrm{OM}_{\mathrm{LOI}}$ data.

The percentage of PIC in the sediments was estimated by LOI at $1000{ }^{\circ} \mathrm{C}$ for $1 \mathrm{~h}$ (Dean, 1974), with a precision from \pm 0.01 to $\pm 0.50 \%$. The PIC values obtained with this method (\% $\left.\mathrm{PIC}_{\mathrm{LOI}}\right)$ compared very satisfactorily with the analysis of $\mathrm{Mg}^{2+}$ and $\mathrm{Ca}^{2+}$ with an inductively coupled plasma atomic emission spectroscopy (ICP-AES) Varian Liberty Series II after extraction with acetic acid (\% PIC ICP-AES) (Fig. 2). The ICP-AES measurements allow

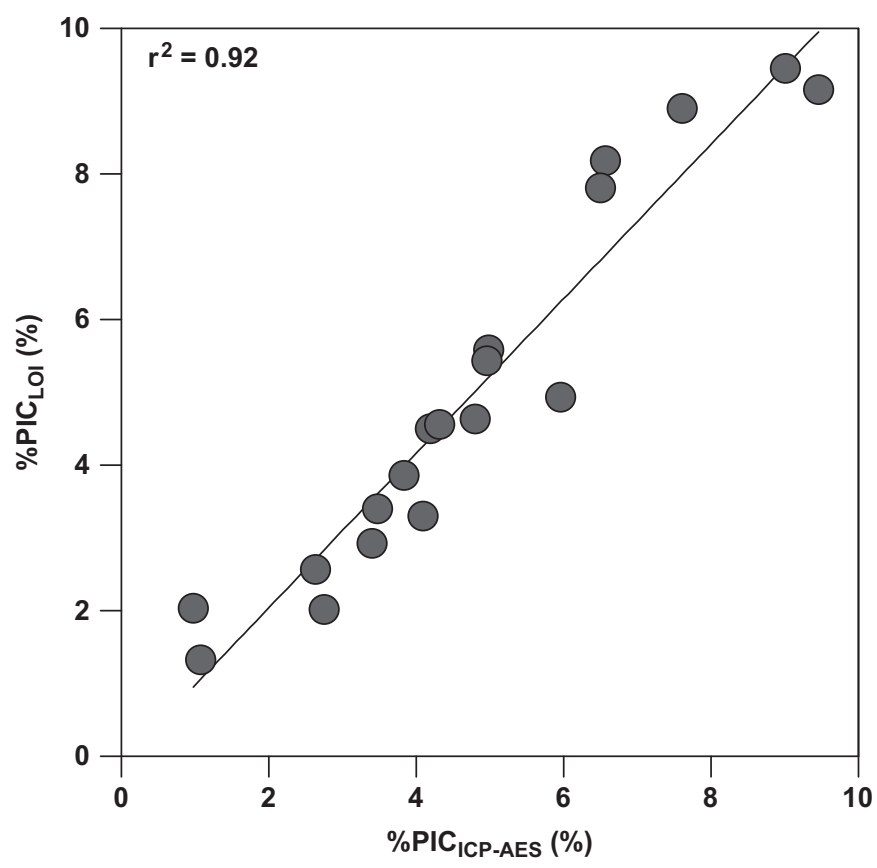

Fig. 2. Linear correlation between \% PIC measured in the sediment by loss on ignition $\left(\% \mathrm{PIC}_{\mathrm{LOI}}\right)$ and by inductively coupled plasma atomic emission spectroscopy (\% PIC ICP-AES$_{\text {) }}$ in the top $1 \mathrm{~cm}$ of each station sampled in June 2006, May 2007 and May 2008 in the Bay of Biscay. 
evaluating the PIC content as the sum of calcium and magnesium carbonates. The carbonates in these sediments contain little $\mathrm{Mg}^{2+}$ (maximum of 4-5 mol\% of $\mathrm{Mg}^{2+}$, data not shown).

The first $2.5 \mathrm{~cm}$ of surface sediment, sub-sampled for TEP determination, were re-suspended in $40 \mathrm{~mL}$ of distilled water and homogenized. Duplicates of $4-12 \mathrm{~mL}$ of the supernatant were filtered through $0.4 \mu \mathrm{m}$ Nuclepore filters and transparent particles were stained with $0.5 \mathrm{~mL}$ of acidic Alcian Blue aqueous solution ( $\mathrm{pH}$ 2.6) according to Passow and Alldredge (1995). The amount of TEP is given in mmol $\mathrm{C} \mathrm{m}^{-2}$ of seafloor at 3 stations (5bis, 9bis and 12) considering a porosity of $46 \%$ in sandy sediments, and a $0.75 \mu \mathrm{g} \mathrm{C}(\mu \mathrm{g} \mathrm{X} \mathrm{eq})^{-1}$ factor to convert TEP concentrations into $C$ units (Passow, 2002).

${ }^{210} \mathrm{~Pb}$ and ${ }^{234} \mathrm{Th}$ are naturally occurring radionuclides in marine sediments, and have been widely used as chronometers for estimating accumulation and mixing rates in marine and lake sediments (Koide et al., 1973; Robbins and Edgington, 1975; Cochran and Aller, 1979; Schmidt et al., 2007). Particles, organic or inorganic, scavenge natural radionuclides in the water column and deposit ${ }^{210} \mathrm{~Pb}$ and ${ }^{234} \mathrm{Th}$ at the seabed in excess $\left({ }^{210} \mathrm{~Pb}_{\mathrm{xs}}\right.$; ${ }^{234} \mathrm{Th}_{\mathrm{xs}}$ ) of that produced within sediments by the decay of their parent isotopes, ${ }^{226} \mathrm{Ra}$ and ${ }^{238} \mathrm{U}$, respectively. As sediments are buried, ${ }^{234} \mathrm{Th}$ and ${ }^{210} \mathrm{~Pb}$ decay with their respective half-life (24.1 d and $22.3 \mathrm{yr}$ ). The distribution of such particle-reactive radionuclides in a sediment column can result from either simple sediment accumulation or mixing plus sediment accumulation (De Master et al., 1985). The effects can be resolved using radionuclides with different half-lives. The ${ }^{210} \mathrm{~Pb}$ method gives an average accumulation rate for the past $100 \mathrm{yr}$ while ${ }^{234} \mathrm{Th}$ is applicable for the past three months. A first test on a core collected in June 2006 showed very low levels of radionuclides in bulk sediments because of the sandy nature of sediment, radionuclides being carried on the fine fraction. Therefore, for the cores obtained in 2007 and 2008, sediment samples were sieved through $63 \mu \mathrm{m}$ and dried at $60{ }^{\circ} \mathrm{C}$. This fraction was used to measure ${ }^{210} \mathrm{~Pb},{ }^{226} \mathrm{Ra},{ }^{234} \mathrm{Th}$, and ${ }^{238} \mathrm{U}$ by gamma spectrometry (Schmidt et al., 2009). The gamma spectrometer is a low background, high-efficiency, well-shaped-detector (Canberra, Ge volume $280 \mathrm{~cm}^{3}$ ), placed in a lead shield and protected from cosmic ray muons by an anti-cosmic shielding made of plastic scintillators. ${ }^{210} \mathrm{~Pb}$ was determined by its specific ray at $46.5 \mathrm{keV}$, ${ }^{226} \mathrm{Ra}$ by the rays of its decay products, at 295 and $352 \mathrm{keV}$ for ${ }^{214} \mathrm{~Pb}$, at $609 \mathrm{keV}$ for ${ }^{214} \mathrm{Bi}$, and ${ }^{234} \mathrm{Th}$ by its rays at 63.2 and $92 \mathrm{keV} .{ }^{238} \mathrm{U}$ is not a gamma emitter, nevertheless its values were determined through ${ }^{234} \mathrm{Th}$ by measuring selected samples a few months later (after the decay of the unsupported fraction of ${ }^{234} \mathrm{Th}$ ). International Atomic Energy Agency standards (RGU-1 and RGTh-1) were used for the calibration of the $\gamma$ detector. The counting error was one standard deviation of counting, and counting times lasted from 4 to $24 \mathrm{~h}$. Excess ${ }^{234} \mathrm{Th}$ and ${ }^{210} \mathrm{~Pb}$ in sediment, i.e., scavenged from seawater, were calculated by subtracting the activity supported by their parent isotope, ${ }^{238} \mathrm{U}$ or ${ }^{226} \mathrm{Ra}$, from the total measured ${ }^{234} \mathrm{Th}$ and ${ }^{210} \mathrm{~Pb}$ activities. For ${ }^{234} \mathrm{Th}$, due to its short half-live, the values were also corrected for radioactive decay that occurred between sample collection and sample counting. Errors on excess values were calculated by propagating errors on activity determinations.

Due to its very short half-life, ${ }^{234} \mathrm{Th}_{\mathrm{xs}}$ should be present only at the water-sediment interface. Its penetration to variable depths indicates efficient mixing of the upper sediments, usually by bioturbation. The simplest way to derive bioturbation rates $\left(D_{\mathrm{b}}\right)$ from radionuclide profiles is to assume mixing as a diffusive process occurring at a constant rate within a surface mixed layer under steady state (Aller and Cochran, 1976; Boudreau, 1986; Schmidt et al., 2002a, 2007). Such assumption allows the determination of $D_{\mathrm{b}}$ from the plot of radionuclide activity as a function of depth, according to

$\left[{ }^{234} \mathrm{Th}_{\mathrm{xs}}\right]_{z}=\left[{ }^{234} \mathrm{Th}_{\mathrm{xs}}\right]_{0} \exp \left(-z \sqrt{\frac{\lambda}{D_{\mathrm{b}}}}\right)$

where $\left[{ }^{234} \mathrm{Th}_{\mathrm{xs}}\right]_{0, z}$ is the activity ( $\mathrm{mBq} \mathrm{g}^{-1}$ ) of excess ${ }^{234} \mathrm{Th}$ at the water-sediment interface, $z$ is the sediment depth, and $\lambda$ is the decay constant of ${ }^{234} \mathrm{Th}\left(10.5 \mathrm{yr}^{-1}\right)$.

We present ${ }^{234}$ Th-derived mixing rates as an indication of particle input over the last few weeks. Such mixing rates must be considered as instantaneous signals (Aller and De Master, 1984; Schmidt et al., 2007).

\section{Results}

\subsection{Surface waters}

The three cruises were carried out after the main spring bloom that peaked in mid-April (associated to diatoms), during the period corresponding from peak to declining normalized water leaving radiance (indicative of the occurrence of coccolithophorid blooms) (Harlay et al., in press; Suykens et al., 2010). Overall, higher remotely sensed Chl- $a$ as well as normalized water leaving radiance was observed at the Goban Spur compared to the La Chapelle Bank during the three years. Some inter-annual variability in remotely sensed Chl- $a$ was observed with highest concentrations in 2008 (up to $5.0 \mu \mathrm{g} \mathrm{L}^{-1}$ at Goban Spur). During the 3 cruises, remote sensing images revealed several patches of cold water (sea surface temperature $<14{ }^{\circ} \mathrm{C}$ ) along the shelf break in the whole study area (Suykens et al., 2010), corresponding to the signature of enhanced vertical mixing due to turbulent dissipation related to the generation of internal tides (Pingree et al., 1999; Wollast and Chou, 2001). Vertical profiles of temperature showed increased stratification over the continental shelf compared to the shelf break during the 3 years. Remote sensing images, vertical profiles of biogeochemical variables $\left(\mathrm{O}_{2}\right.$, partial pressure of $\mathrm{CO}_{2}$, dissolved inorganic nutrients, Chl- $a$, Harlay et al., 2009, in press; Suykens et al., 2010; Harlay, Chou, Suykens, Borges, unpublished) and process measurements (primary production, calcification, planktonic community respiration, bacterial production; Harlay et al., 2009, in press; Harlay, Chou, Suykens, Borges, unpublished) suggest that the sampling was carried out at the onset of the coccolithophorid bloom during the May 2007 and 2008 cruises and towards the declining bloom phase, during the June 2006 cruise. Upwelling of deep cold water brings nutrients to surface waters and sustains phytoplankton activity along the continental margin as well as a coccolithophorid bloom along the shelf edge, in the warmer and more stratified waters (Harlay et al., 2010, in press; Suykens et al., 2010). In May 2007, wind speeds and storm events (ship-board measurements averaged $10 \mathrm{~m} \mathrm{~s}^{-1}$ with a maximum of $30 \mathrm{~m} \mathrm{~s}^{-1}$ ) were higher than in May 2008 (average wind speed of $7 \mathrm{~m} \mathrm{~s}^{-1}$ with a maximum of $17 \mathrm{~m} \mathrm{~s}^{-1}$ ), and than June 2006 (average wind speed of $7 \mathrm{~m} \mathrm{~s}^{-1}$ and maximum of $15 \mathrm{~m} \mathrm{~s}^{-1}$ ).

\subsection{Bottom water characteristics}

Bottom waters sampled from 7 to $30 \mathrm{~m}$ above the sea floor were characterized by temperatures ranging between 10.5 and $11.9^{\circ} \mathrm{C}$ and salinities ranging between 35.37 and 35.61 , and were well oxygenated $\left(\% \mathrm{O}_{2}>80 \%\right)$ (Table 1 ) as also reported at the Goban Spur at depths between 208 and 4460 m (Heip et al., 2001). The lowest $\% \mathrm{O}_{2}$ values in bottom waters were observed at the 2 deepest stations ( $80.4 \%$ at $521 \mathrm{~m}$ depth (station 6 in May 2008 ) and $85.3 \%$ at $680 \mathrm{~m}$ depth (station 2 in June 2006)), while 
the highest values (96.7\%) were observed in May 2007 (Table 1). $\mathrm{NO}_{3}^{-}$ranged from 3.9 to $11.1 \mu \mathrm{mol} \mathrm{L}^{-1}$ and DSi ranged from 1.4 to $4.7 \mu \mathrm{mol} \mathrm{L}^{-1}$ (Table 1 ), in agreement with values previously reported at similar depths at La Chapelle Bank (Wollast and Chou, 2001; Hydes et al., 2001). Chl- $a$ and Phaeo concentrations of bottom waters were low (0.03-0.58 and $0.04-0.68 \mu \mathrm{g} \mathrm{L}^{-1}$, respectively) and the highest concentrations were observed during the May 2008 cruise (Table 1). SPM values ranged from 0.20 to $1.46 \mathrm{mg} \mathrm{L}^{-1}$ (Table 1), falling in the lower end of the range observed by Thomsen and van Weering (1998) (0.2-10.0 $\mathrm{mg} \mathrm{L}^{-1}$ in the BBL from 5 to $50 \mathrm{~cm}$ height above the seafloor) at Goban Spur at depths between 208 and $4460 \mathrm{~m}$. POC and PIC concentrations ranged from 0.014 to $0.097 \mathrm{mg} \mathrm{L}^{-1}$ and from 0.005 to $0.072 \mathrm{mg} \mathrm{L}^{-1}$, respectively (Table 1 ). The concentrations of POC were in agreement with the values of $0.04 \mathrm{mg} \mathrm{L}^{-1}$ at $208 \mathrm{~m}$ depth and $0.08 \mathrm{mg} \mathrm{L}^{-1}$ at $668 \mathrm{~m}$ depth in the BBL at Goban Spur reported by Thomsen and van Weering (1998).

\subsection{Sediments}

The overall median grain size was $285 \mu \mathrm{m}$ (excluding the two coarser stations 1 and 8 in May 2008), at the La Chapelle Bank and Goban Spur (Table 2). The lowest median grain sizes were observed over the Goban Spur $(262 \mu \mathrm{m})$ and in the two upper slope stations $(190 \mu \mathrm{m}$ at $521 \mathrm{~m}$ depth (station 2 in 2006) and $127 \mu \mathrm{m}$ at $680 \mathrm{~m}$ depth (station 6 in 2008)). This distribution is in agreement with previously published values along the northeast shelf break (Reynaud et al., 1999; van Weering et al., 2001).

Surface sediment Chl- $a$ content showed distinct ranges between the 3 cruises: the highest values, were observed in May 2008 $\left(0.21-0.95 \mu \mathrm{g} \mathrm{g}^{-1}\right)$, intermediate values in May $2007(0.08-$ $\left.0.27 \mu \mathrm{g} \mathrm{g}^{-1}\right)$ and the lowest values $\left(0.01-0.05 \mu \mathrm{g} \mathrm{g}^{-1}\right)$ in June 2006 (Fig. 3 and Table 2). In May 2008, high Chl- $a$ values were also observed into the top $5 \mathrm{~cm}$ of the sediments indicative of recent deposition of phytoplankton material (except station 9bis). Surface sediment Phaeo values in May 2007 and 2008 were comparable, ranging between 0.3 and $2.2 \mu \mathrm{g} \mathrm{g}^{-1}$ and were lower in June 2006, when they ranged between 0.02 and $1.03 \mu \mathrm{g} \mathrm{g}^{-1}$ (Table 2). Chl-a:Phaeo ratios in the top $5 \mathrm{~cm}$ of the sediments were highest in May 2008 compared to the other two cruises (Fig. 3), indicating more recently deposited phytoplankton particles.
The sediment $\% \mathrm{OM}_{\mathrm{LOI}}$ ranged between $1.4 \%$ and $4.0 \%$ (Table 2 ) and falls in the range observed by Epping et al. (2002) at the continental margin and shelf slope (depth $<1000 \mathrm{~m}$ ) of the Iberian margin (0.5-4.5\%). The sediments were relatively rich in PIC (\% PIC between 1.3\% and 9.5\%) (Table 2 ) and fall in the range reported by Epping et al. (2002) at the Iberian margin (0.6-9.0\%) at depths between 104 and $4941 \mathrm{~m}$. Flach and Heip (1996) observed higher $\% \mathrm{CaCO}_{3}$ from $\sim 20 \%$ at $208 \mathrm{~m}$ up to $\sim 70 \%$ at
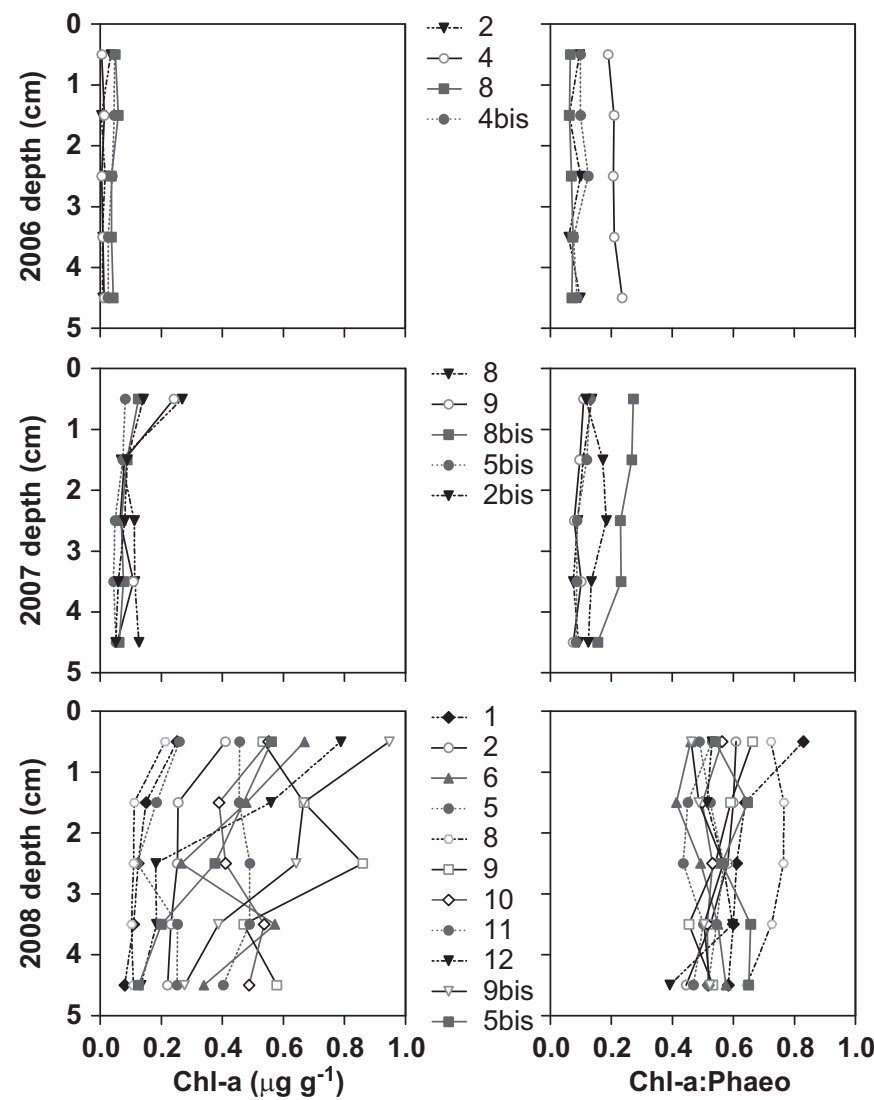

Fig. 3. Profiles in the sediment of the northern Bay of Biscay of Chl- $a$ (in $\mu \mathrm{g} \mathrm{g}^{-1}$ ) and Chl-a:Phaeo in June 2006, May 2007 and May 2008.

Table 2

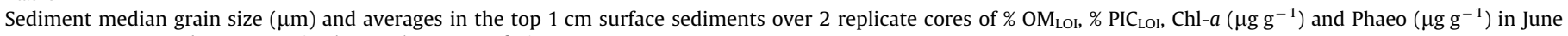
2006, May 2007 and May 2008 in the northern Bay of Biscay.

\begin{tabular}{|c|c|c|c|c|c|c|}
\hline Station & Date & $\begin{array}{l}\text { Median } \\
\text { grain size }(\mu \mathrm{m})\end{array}$ & $\% \mathrm{OM}_{\text {LOI }}(\%)$ & \% PIC & Chl-a $\left(\mu g^{-1}\right)$ & Phaeo $\left(\mu \mathrm{g} \mathrm{g}^{-1}\right)$ \\
\hline 2 & $1 / 06 / 2006$ & 91 & 2.86 & 4.64 & 0.04 & 0.37 \\
\hline 4 & $2 / 06 / 2006$ & 228 & 1.42 & 2.93 & 0.01 & 0.03 \\
\hline 8 & $6 / 06 / 2006$ & 204 & 2.43 & 3.31 & 0.05 & 0.77 \\
\hline 4bis & $8 / 06 / 2006$ & 126 & 1.46 & 4.51 & 0.05 & 0.48 \\
\hline 8 & $13 / 05 / 2007$ & 237 & 1.93 & 6.76 & 0.27 & 1.96 \\
\hline 9 & $14 / 05 / 2007$ & 113 & 2.36 & 3.40 & 0.24 & 2.20 \\
\hline 8bis & $21 / 05 / 2007$ & 270 & 1.76 & 4.56 & 0.13 & 0.46 \\
\hline 5bis & $22 / 05 / 2007$ & 326 & 2.73 & 9.16 & 0.08 & 0.63 \\
\hline 2bis & $24 / 05 / 2007$ & 304 & 2.86 & 8.19 & 0.14 & 1.22 \\
\hline 1 & $7 / 05 / 2008$ & 819 & 4.04 & 9.45 & 0.25 & 0.31 \\
\hline 2 & $8 / 05 / 2008$ & 346 & 3.24 & 8.91 & 0.41 & 0.67 \\
\hline 6 & $9 / 05 / 2008$ & 51 & 3.45 & 2.57 & 0.67 & 1.45 \\
\hline 5 & $10 / 05 / 2008$ & 252 & 1.88 & 5.58 & 0.26 & 0.49 \\
\hline 8 & $11 / 05 / 2008$ & 1221 & 1.96 & 5.44 & 0.21 & 0.31 \\
\hline 9 & $12 / 05 / 2008$ & 185 & 3.03 & 3.86 & 0.53 & 0.79 \\
\hline 10 & $13 / 05 / 2008$ & 86 & 1.82 & 2.02 & 0.55 & 1.01 \\
\hline 11 & $14 / 05 / 2008$ & 82 & 2.01 & 2.04 & 0.46 & 0.94 \\
\hline 12 & $18 / 05 / 2008$ & 145 & 1.47 & 1.33 & 0.79 & 1.50 \\
\hline 9bis & $21 / 05 / 2008$ & 81 & 3.41 & 4.94 & 0.95 & 2.05 \\
\hline 5bis & $22 / 05 / 2008$ & 273 & 2.33 & 7.81 & 0.56 & 1.05 \\
\hline
\end{tabular}


$4460 \mathrm{~m}$ in Goban Spur. Macroscopic and microscopic (with optical microscope) examinations of the surface sediments suggest that most of the PIC was related to debris of bivalve shells.

Due to the dilution by the sandy fraction, radionuclide measurements were done on the fine fraction $(<63 \mu \mathrm{m})$. Only surface sediments, with a fine fraction higher than $1.5 \%$, allowed recovering enough material for measurements. Therefore, no data were available for the 2006 cruise when the fine fraction was not separated from the coarser fractions. The activities of ${ }^{234} \mathrm{Th}_{\mathrm{xs}}$ and ${ }^{210} \mathrm{~Pb}_{\mathrm{xs}}$ were obtained at stations 8, 9 and 5bis in May 2007 and at stations 5, 6, 9, 10, 11 and 12 in May 2008 (Table 3). The activities of ${ }^{210} \mathrm{~Pb}_{\mathrm{xs}}$ presented a low variability $\left(199-344 \mathrm{mBq} \mathrm{g}^{-1}\right)$ in surface sediments, except at the deepest station (6 in 2008) and station 10 in 2008 . This is due to the fact that ${ }^{210} \mathrm{~Pb}$ is scavenged throughout the water column and its surface activity is mainly related to the water column depth. ${ }^{234} \mathrm{Th}_{\mathrm{xs}}$ show a wider range in activities $\left(515-3364 \mathrm{mBq} \mathrm{g}^{-1}\right)$. As ${ }^{234} \mathrm{Th}_{\mathrm{xs}}$ has a short half-live, surface activities are expected to be less related to water column depth. The high activities of ${ }^{234} \mathrm{Th}_{\mathrm{xs}}$ in surface sediments in 2008 are in the lower range of the values recorded in surface sediment traps in the north-western Mediterranean (Schmidt et al., 2002b). From ${ }^{234} \mathrm{Th}_{\mathrm{xs}}$ profiles in the sediment, an instantaneous $D_{\mathrm{b}}$ was computed (Table 3), ranging between 4.5 and $26.5 \mathrm{~cm}^{2} \mathrm{yr}^{-1}$. Such values are usually encountered in coastal systems (Schmidt et al., 2002a, 2007).

The water-sediment $\mathrm{O}_{2}$ fluxes measured in the core incubations give an estimate of diffusive oxygen rates as well as fauna mediated $\mathrm{O}_{2}$ consumption. Overall, $\mathrm{FO}_{2}$ values were low and ranged between -2.0 and $-9.0 \mathrm{mmol} \mathrm{O}_{2} \mathrm{~m}^{-2} \mathrm{~d}^{-1}$ (Table 4). The $\mathrm{FO}_{2}$ values were higher during the May 2008 cruise, except for stations 4 and 8 . In May 2007, $\mathrm{FO}_{2}$ values were less variable spatially. The $\mathrm{FO}_{2}$ values we report are within the range of watersediment $\mathrm{O}_{2}$ fluxes $\left(-3.5\right.$ to $\left.-8 \mathrm{mmol} \mathrm{O}_{2} \mathrm{~m}^{-2} \mathrm{~d}^{-1}\right)$ reported by Lohse et al. (1998) at the Goban Spur upper slope (208 and $670 \mathrm{~m}$ ). Epping et al. (2002) reported modeled values of -2.0 to $-5.0 \mathrm{mmol} \mathrm{O}_{2} \mathrm{~m}^{-2} \mathrm{~d}^{-1}$ at the Iberian margin sediments in MayJune 1999 at depths $<1000 \mathrm{~m}$. Yet, the $\mathrm{FO}_{2}$ values we report fall in the lower end of the range reported by Gazeau et al. (2004) for continental shelves and estuaries in Europe $(-11.0$ to $-210.0 \mathrm{mmol} \mathrm{O}_{2} \mathrm{~m}^{-2} \mathrm{~d}^{-1}$ ), and of the range of permeable sediments ( -10.0 to $-120.0 \mathrm{mmol} \mathrm{O}_{2} \mathrm{~m}^{-2} \mathrm{~d}^{-1}$ ) reported by Reimers et al. (2004) and Rusch et al. (2006).

The FTA fluxes $\left(-1.1\right.$ to $\left.3.7 \mathrm{mmol} \mathrm{m}^{-2} \mathrm{~d}^{-1}\right)$ fall in the range $(0.4$ to $5.5 \mathrm{mmol} \mathrm{m}^{-2} \mathrm{~d}^{-1}$ ) reported by Silverberg et al. (2000) on the eastern Canadian continental margin and in the lower end of the measurements from 600 to $850 \mathrm{~m}$ depth (1.4 to $10.7 \mathrm{mmol} \mathrm{m}^{-2} \mathrm{~d}^{-1}$ ) by Jahnke and Jahnke (2000) on the U.S. Mid-Atlantic continental slope. The reported FTA flux values were negative at some stations. We do not think this has a biogeochemical significance, and is most probably related to the low ratio of signal to noise (i.e., sensitivity of the method) due to the overall low $\mathrm{CaCO}_{3}$ dissolution rates (hence, FTA signals, as discussed hereafter).

$\mathrm{FNO}_{3}^{-}$values ranged from -0.45 to $1.18 \mathrm{mmol} \mathrm{m}^{-2} \mathrm{~d}^{-1}$ (Table 4$)$ and are higher than those reported by Lohse et al. (1998) at the Goban Spur ( 0.02 to $0.25 \mathrm{mmol} \mathrm{m}^{-2} \mathrm{~d}^{-1}$ ) at depths from 208 to $1500 \mathrm{~m}$. Epping et al. (2002) reported values of -0.20 to $0.50 \mathrm{mmol} \mathrm{m} \mathrm{m}^{-2} \mathrm{~d}^{-1}$ at the Iberian margin sediments at depths $<1000 \mathrm{~m}$. FDSi values ranged from 0.05 to $0.95 \mathrm{mmol} \mathrm{m}^{-2} \mathrm{~d}^{-1}$ (Table 4) and encompass the range reported by Lohse et al. (1998) at the Goban Spur $\left(0.40\right.$ to $\left.0.85 \mathrm{mmol} \mathrm{m}^{-2} \mathrm{~d}^{-1}\right)$ at depths $<1000 \mathrm{~m}$.

Table 3

Profiles of ${ }^{210} \mathrm{~Pb}_{\mathrm{xs}}$ and ${ }^{234} \mathrm{Th}_{\mathrm{xs}}$ activities ( $\mathrm{mBq} \mathrm{g}{ }^{-1}$ ) in the $<63 \mu \mathrm{m}$ fraction of the sediment in May 2007 and 2008 in the northern Bay of Biscay (n.d.: the fine fraction was negligible). ${ }^{234} \mathrm{Th}_{\mathrm{xs}}$-derived mixing rates $\left(D_{\mathrm{b}}\right.$ in $\left.\mathrm{cm}^{2} \mathrm{yr}^{-1}\right)$ are given as an estimate of the instantaneous mixing of sediment. There is only one profile of ${ }^{210} \mathrm{~Pb}_{\mathrm{xs}}$ at the station 9 (2007), which presents a significant decrease in depth, corresponding to a sedimentation rate of $0.05 \mathrm{~cm} \mathrm{yr}^{-1}$.

\begin{tabular}{|c|c|c|c|c|c|}
\hline Station & Date & Depth $(\mathrm{cm})$ & ${ }^{210} \mathrm{~Pb}_{\mathrm{xs}}\left(\mathrm{mBq} \mathrm{g}^{-1}\right)$ & ${ }^{234} \mathrm{Th}_{\mathrm{xs}}\left(\mathrm{mBq} \mathrm{g}^{-1}\right)$ & $D_{\mathrm{b}}\left(\mathrm{cm}^{2} \mathrm{yr}^{-1}\right)$ \\
\hline 8 & $13 / 05 / 2007$ & 0.5 & $277 \pm 23$ & $3058 \pm 28$ & 12.4 \\
\hline 8 & $13 / 05 / 2007$ & 1.5 & $169 \pm 14$ & $640 \pm 13$ & \\
\hline 8 & $13 / 05 / 2007$ & 2.5 & $266 \pm 40$ & $316 \pm 20$ & \\
\hline 8 & $13 / 05 / 2007$ & 3.5 & $216 \pm 13$ & $181 \pm 10$ & \\
\hline 8 & $13 / 05 / 2007$ & 5.5 & $180 \pm 17$ & & \\
\hline 8 & $13 / 05 / 2007$ & 9.5 & $115 \pm 10$ & & \\
\hline 9 & $14 / 05 / 2007$ & 0.5 & $233 \pm 18$ & $1832 \pm 19$ & 4.5 \\
\hline 9 & $14 / 05 / 2007$ & 1.5 & $197 \pm 18$ & $397 \pm 13$ & \\
\hline 9 & $14 / 05 / 2007$ & 3.5 & $169 \pm 10$ & & \\
\hline 9 & $14 / 05 / 2007$ & 6.5 & $109 \pm 10$ & & \\
\hline 9 & $14 / 05 / 2007$ & 9.5 & $23 \pm 5$ & & \\
\hline 9 & $14 / 05 / 2007$ & 11.5 & $6 \pm 4$ & & \\
\hline 8bis & $21 / 05 / 2007$ & 0.5 & n.d. & & \\
\hline 5bis & $22 / 05 / 2007$ & 0.5 & $344 \pm 50$ & $2134 \pm 47$ & 26.5 \\
\hline 5bis & $22 / 05 / 2007$ & 1.5 & $270 \pm 24$ & $481 \pm 16$ & \\
\hline 5bis & $22 / 05 / 2007$ & 3.5 & $418 \pm 19$ & $272 \pm 11$ & \\
\hline 5bis & $22 / 05 / 2007$ & 6.5 & $359 \pm 35$ & & \\
\hline 2bis & $24 / 05 / 2007$ & 0.5 & n.d. & & \\
\hline 6 & $9 / 05 / 2008$ & 0.5 & $465 \pm 34$ & $515 \pm 15$ & 4.9 \\
\hline 6 & $9 / 05 / 2008$ & 1.5 & $343 \pm 17$ & $120 \pm 12$ & \\
\hline 5 & $10 / 05 / 2008$ & 0.5 & $302 \pm 67$ & $3364 \pm 55$ & 11.8 \\
\hline 5 & $10 / 05 / 2008$ & 1.5 & $362 \pm 64$ & $1312 \pm 31$ & \\
\hline 5 & $10 / 05 / 2008$ & 2.5 & $296 \pm 20$ & $508 \pm 11$ & \\
\hline 9 & $12 / 05 / 2008$ & 0.5 & $250 \pm 28$ & $582 \pm 16$ & 6.4 \\
\hline 9 & $12 / 05 / 2008$ & 1.5 & $234 \pm 23$ & $162 \pm 11$ & \\
\hline 10 & $13 / 05 / 2008$ & 0.5 & $474 \pm 53$ & $1430 \pm 30$ & 4.5 \\
\hline 10 & $13 / 05 / 2008$ & 1.5 & $240 \pm 48$ & $313 \pm 17$ & \\
\hline 10 & $13 / 05 / 2008$ & 2.5 & $282 \pm 29$ & & \\
\hline 10 & $13 / 05 / 2008$ & 3.5 & $301 \pm 23$ & & \\
\hline 10 & $13 / 05 / 2008$ & 5.5 & $223 \pm 13$ & & \\
\hline 10 & $13 / 05 / 2008$ & 7.5 & $221 \pm 19$ & & \\
\hline 11 & $14 / 05 / 2008$ & 0.5 & $419 \pm 46$ & $595 \pm 20$ & \\
\hline 12 & $18 / 05 / 2008$ & 0.5 & $199 \pm 32$ & $1100 \pm 21$ & 7.2 \\
\hline 12 & $18 / 05 / 2008$ & 1.5 & $66 \pm 18$ & $327 \pm 13$ & \\
\hline
\end{tabular}


Table 4

Average \pm standard deviation of water-sediment fluxes of $\mathrm{O}_{2}, \mathrm{TA}, \mathrm{NO}_{3}^{-}$, DSi $\left(\mathrm{mmol} \mathrm{m}^{-2} \mathrm{~d}^{-1}\right.$ ), in June 2006 , May 2007 and May 2008 in the northern Bay of Biscay.

\begin{tabular}{|c|c|c|c|c|c|}
\hline Station & Date & $\mathrm{FO}_{2}\left(\mathrm{mmol} \mathrm{m}^{-2} \mathrm{~d}^{-1}\right)$ & FTA $\left(\mathrm{mmol} \mathrm{m} \mathrm{m}^{-2} \mathbf{d}^{-1}\right)$ & $\mathrm{FNO}_{3}\left(\mathrm{mmol} \mathrm{m}^{-2} \mathrm{~d}^{-1}\right)$ & FDSi $\left(\mathrm{mmol} \mathrm{m}^{-2} \mathrm{~d}^{-1}\right)$ \\
\hline 2 & $1 / 06 / 2006$ & $-3.81 \pm 0.31$ & $0.57 \pm 1.48$ & $0.19 \pm 1.23$ & $0.63 \pm 0.15$ \\
\hline 4 & $2 / 06 / 2006$ & $-2.35 \pm 0.90$ & $0.99 \pm 0.85$ & $1.18 \pm 1.19$ & $0.05 \pm 0.02$ \\
\hline 8 & $6 / 06 / 2006$ & $-4.66 \pm 1.52$ & $1.49 \pm 1.21$ & $0.25 \pm 0.09$ & $0.59 \pm 0.24$ \\
\hline 4bis & $8 / 06 / 2006$ & $-7.21 \pm 1.15$ & $1.77 \pm 2.21$ & $0.32 \pm 0.13$ & $0.61 \pm 0.20$ \\
\hline 8 & $13 / 05 / 2007$ & $-5.84 \pm 1.44$ & $-0.22 \pm 1.05$ & $0.03 \pm 0.16$ & $0.80 \pm 0.37$ \\
\hline 9 & $14 / 05 / 2007$ & $-5.97 \pm 1.46$ & $2.29 \pm 2.15$ & $-0.42 \pm 0.43$ & $0.55 \pm 0.39$ \\
\hline 8bis & $21 / 05 / 2007$ & $-4.71 \pm 0.31$ & $1.18 \pm 0.92$ & $0.18 \pm 0.13$ & $0.53 \pm 0.19$ \\
\hline 5 bis & $22 / 05 / 2007$ & $-5.72 \pm 0.70$ & $1.83 \pm 1.14$ & $0.81 \pm 0.11$ & $0.13 \pm 0.06$ \\
\hline $2 \mathrm{bis}$ & $24 / 05 / 2007$ & $-5.27 \pm 0.83$ & $0.41 \pm 0.78$ & $0.29 \pm 0.43$ & $0.50 \pm 0.12$ \\
\hline 1 & $7 / 05 / 2008$ & $-6.16 \pm 1.38$ & $0.52 \pm 0.76$ & $0.51 \pm 0.20$ & $0.11 \pm 0.05$ \\
\hline 2 & $8 / 05 / 2008$ & $-6.60 \pm 0.66$ & $0.70 \pm 1.67$ & $-0.13 \pm 0.27$ & $0.26 \pm 0.17$ \\
\hline 6 & $9 / 05 / 2008$ & $-4.74 \pm 0.34$ & $3.66 \pm 0.36$ & $-0.45 \pm 0.63$ & $0.69 \pm 0.03$ \\
\hline 5 & $10 / 05 / 2008$ & $-3.67 \pm 1.30$ & $0.58 \pm 0.27$ & $0.13 \pm 0.28$ & $0.40 \pm 0.26$ \\
\hline 8 & $11 / 05 / 2008$ & $-4.12 \pm 1.15$ & $0.43 \pm 2.20$ & $0.25 \pm 0.30$ & $0.68 \pm 0.38$ \\
\hline 9 & $12 / 05 / 2008$ & $-7.25 \pm 1.54$ & $-1.03 \pm 0.73$ & $0.10 \pm 0.23$ & $0.70 \pm 0.14$ \\
\hline 10 & $13 / 05 / 2008$ & $-6.54 \pm 2.15$ & $1.19 \pm 1.37$ & $0.20 \pm 0.25$ & $0.40 \pm 0.14$ \\
\hline 11 & $14 / 05 / 2008$ & $-5.44 \pm 0.14$ & $-0.31 \pm 0.98$ & $0.04 \pm 0.23$ & $0.87 \pm 0.44$ \\
\hline 12 & $18 / 05 / 2008$ & $-6.82 \pm 0.93$ & $0.22 \pm 1.59$ & $-0.19 \pm 0.32$ & $0.57 \pm 0.35$ \\
\hline 9bis & $21 / 05 / 2008$ & $-8.39 \pm 0.30$ & $0.87 \pm 1.19$ & $-0.23 \pm 0.25$ & $0.95 \pm 0.29$ \\
\hline 5 bis & $22 / 05 / 2008$ & $-4.13 \pm 1.83$ & $1.57 \pm 0.79$ & $0.51 \pm 0.24$ & $0.39 \pm 0.34$ \\
\hline
\end{tabular}
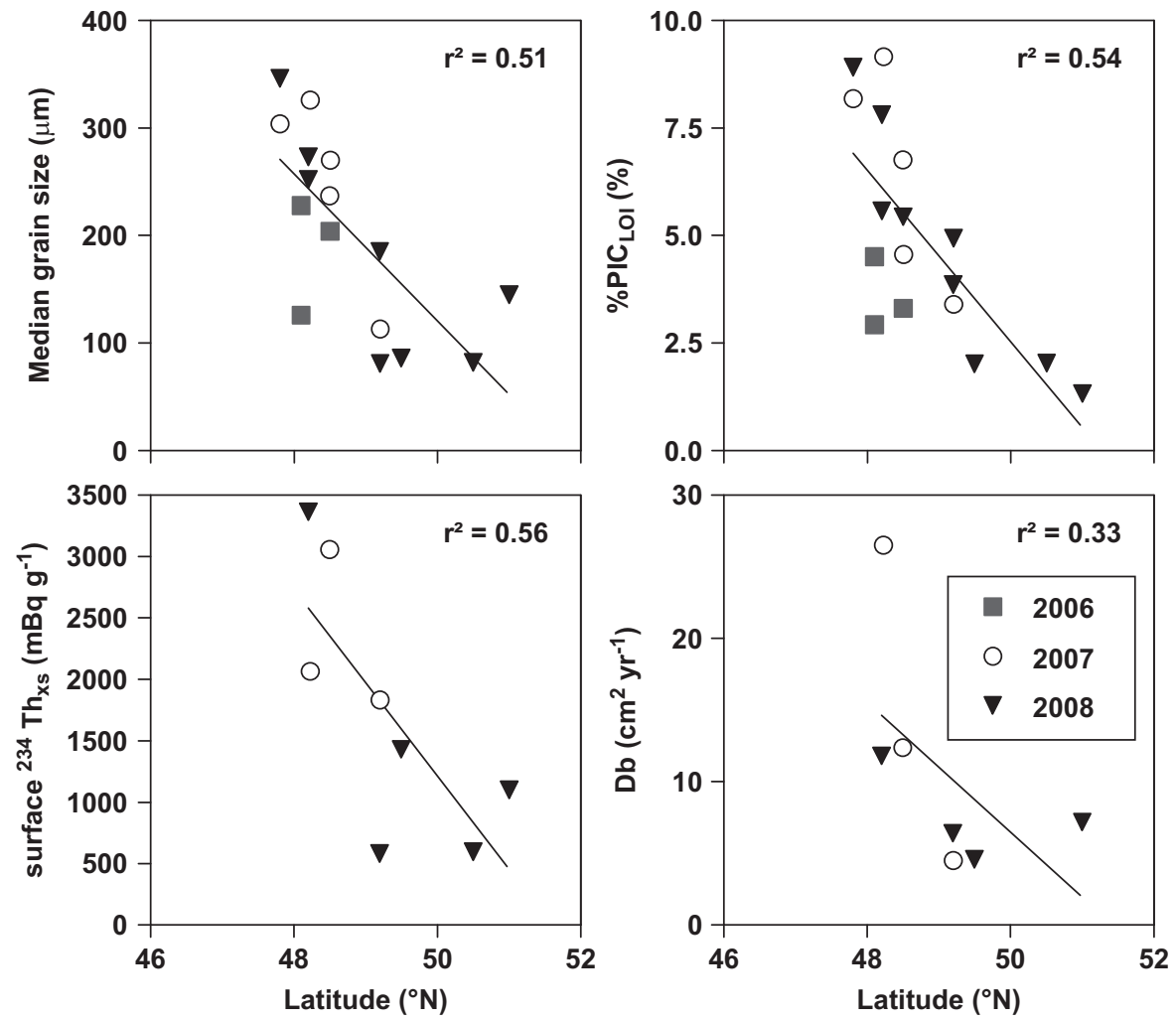

Fig. 4. Median sediment grain size $(\mu \mathrm{m}), \% \mathrm{PIC}_{\mathrm{LOI}}(\%),{ }^{234} \mathrm{Th}_{\mathrm{xs}}$ activity $\left(\mathrm{mBq} \mathrm{g}^{-1}\right)$ for the surface sediments $($ top $1 \mathrm{~cm})$ and ${ }^{234} \mathrm{Th}_{\mathrm{xs}}-\mathrm{derived} \mathrm{mixing} \mathrm{rates}\left(D_{\mathrm{b}}\right.$ in $\left.\mathrm{cm}^{2} \mathrm{yr}^{-1}\right)$ as a function of latitude of the shallow stations (depth $<200 \mathrm{~m}$ ) in the northern Bay of Biscay, in June 2006, May 2007, and May 2008. Solid lines represent the linear regressions.

\section{Discussion}

\subsection{Spatial patterns}

From La Chapelle Bank towards Goban Spur, the sediments became finer as indicated by the variation of the median grain size with latitude (Fig. 4), in agreement with a northward along slope current leaving coarser material over the more turbulent La Chapelle Bank and transporting finer sediments further north towards the Goban Spur (Pingree and Le Cann, 1989; Pingree and
New, 1995). This pattern in grain size is consistent with the decrease of \% PIC $_{\mathrm{LOI}}$ with latitude (Fig. 4); the visual inspection of the sediments showed the presence of more or less large debris of bivalve shells contributing to the coarse fraction of the sediment. These patterns in grain size and \% $\mathrm{PIC}_{\mathrm{LOI}}$ suggest that the decrease of surface ${ }^{234} \mathrm{Th}_{\mathrm{xs}}$ and $D_{\mathrm{b}}$ with latitude (Fig. 4 ) is indicative of high re-suspension rather than bioturbation over the La Chapelle Bank and transport northward along the shelf edge towards the Goban Spur. The negative relationship between ${ }^{234} \mathrm{Th}_{\mathrm{xs}}$ activity and Chl- $a$ content $\left(r^{2}=0.39\right)$ (Fig. 5) indicated a quick dilution in the 

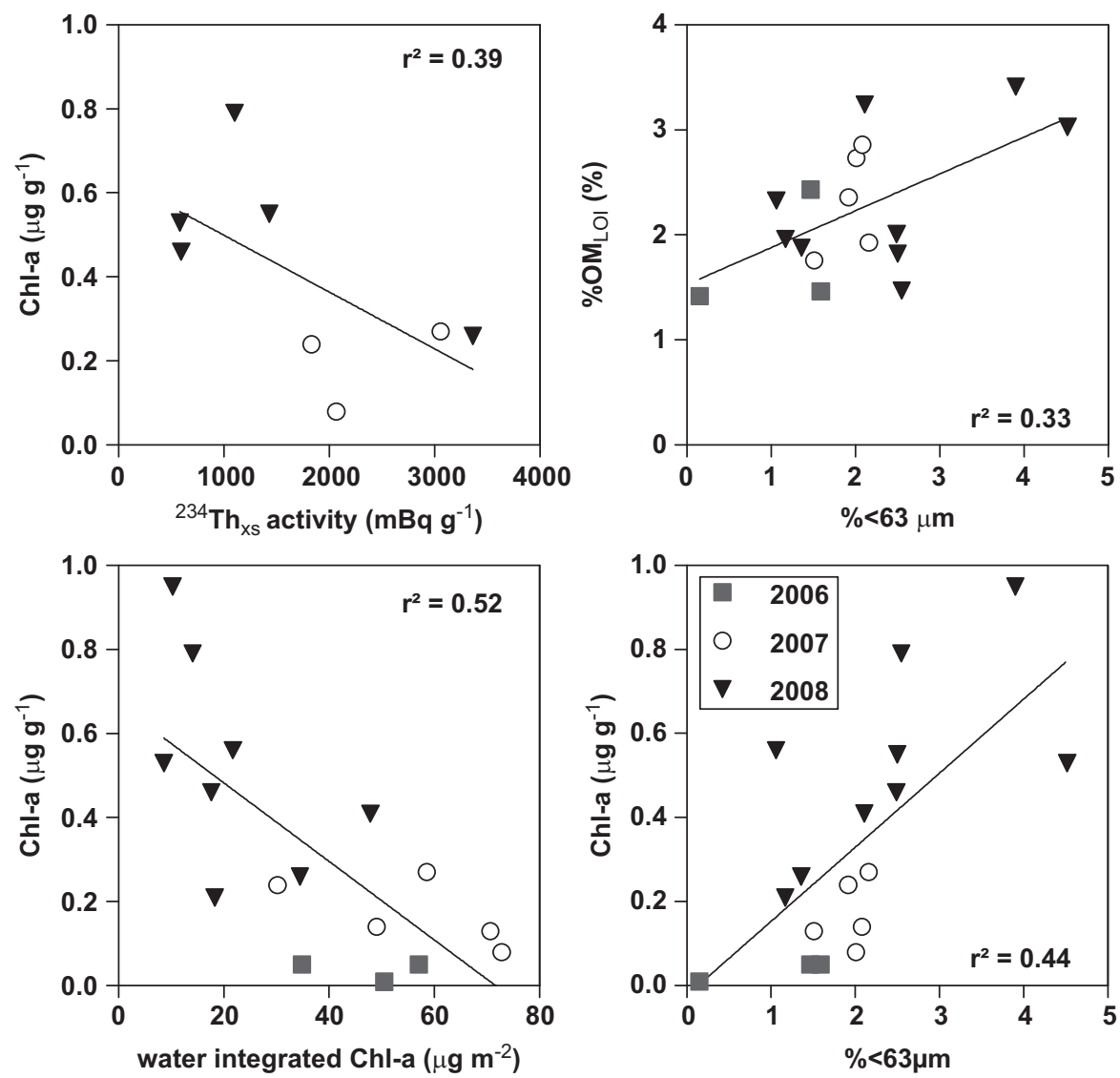

Fig. 5. Surface sediment (top $1 \mathrm{~cm}$ ) Chl- $a$ content $\left(\mu \mathrm{g} \mathrm{g}{ }^{-1}\right)$ versus surface sediment ${ }^{234} \mathrm{Th}_{\mathrm{xs}}$ activity $\left(\mathrm{mBq} \mathrm{g}^{-1}\right)$ and versus the integrated water column Chl- $a\left(\mathrm{mg} \mathrm{m}^{-2}\right.$ ), grain size content $<63 \mu \mathrm{m}(\%)$ versus \% $\mathrm{OM}_{\mathrm{LO}}$ and versus surface sediment Chl-a content $\left(\mu \mathrm{g} \mathrm{g}^{-1}\right.$ ) of the surface sediments (top $1 \mathrm{~cm}$ ) of the shallow stations (depth $<200 \mathrm{~m}$ ) in the northern Bay of Biscay in June 2006, May 2007 and May 2008. Solid lines represent the linear regressions.

sediment of "freshly" deposited matter over the La Chapelle Bank due to strong mixing. An enrichment of older OM (indicated by \% $\mathrm{OM}_{\mathrm{LOI}}$ ) as well as recently deposited matter (indicated by Chl- $a$ ) was observed in relation to finer grain fraction (Fig. 5). The mixing depth and intensity are usually much lower at the shelf edge and on the slope compared to near-shore coastal systems (van Weering et al., 2001; Schmidt et al., 2002a). Previous work by Reynaud et al. (1999) in the La Chapelle Bank area showed high reworking events of the sand banks (Fig. 1) by waves and tides, inducing the winnowing of the fine fraction. The resuspended sediments are then transported across the banks dominated by shelf residual currents and long-term drift (Reynaud et al., 1999). Profiles of ${ }^{210} \mathrm{~Pb}_{\mathrm{xs}}$ were almost constant over the top $\sim 10 \mathrm{~cm}$, for every cruise, indicating a strong mixing of these sediments (Table 3). This is in agreement with the observations by Rusch et al. (2006 and references therein) that higher current regimes over a sandy floor can flush the sediment surface down to several $\mathrm{cm}$ depth. This is also in agreement with the observed successive re-suspension and re-deposition of particles in sediments of the Bay of Biscay (Thomsen and van Weering, 1998). Therefore ${ }^{210} \mathrm{~Pb}_{\mathrm{xs}}$ profiles registered mixing events, and are not appropriate for sedimentation rate determination, which is very low in the area (Reynaud et al., 1999; Thomsen and van Weering, 1998; Heip et al., 2001; van Weering et al., 2001).

The higher water column integrated Chl- $a$ content (Fig. 5) was consistent with higher primary production at La Chapelle Bank than at Goban Spur (Joint et al., 2001) due to higher vertical mixing at La Chapelle Bank related to turbulent dissipation of internal tides (Wollast and Chou, 2001). The La Chapelle Bank area appeared to be the area of the onset of the phytoplankton blooms with higher primary production (as reported by Harlay et al. (in press) in June 2006) upon which the water mass stratifies and the bloom ages as it moves over the shelf. The negative relationship between the Chl- $a$ content of the sediment interface and water column integrated $\mathrm{Chl}-a$ (Fig. 5) indicates a decoupling between organic $C$ production in surface waters (around La Chapelle Bank) and deposition in the sediments (towards Goban Spur).

\subsection{Temporal patterns}

${ }^{234} \mathrm{Th}_{\mathrm{xs}}$ activities at the water-sediment interface are mainly related to freshly deposited particles due to the rapid settling particles from the surface water, associated with pelagic production, or due to re-suspended particles, that scavenged ${ }^{234} \mathrm{Th}$ in the deep bottom layer. Besides a spatial pattern, no temporal trend with regards to for instance sediment Chl- $a$ content during the different cruises could be observed from ${ }^{234} \mathrm{Th}_{\mathrm{xs}}$ activities. This suggests that scavenging of ${ }^{234} \mathrm{Th}$ by re-suspension was the most important process. Chl- $a$ in the sediments was highest in 2008 indicating that more recently phytoplanktonic OM was deposited (Fig. 3) as confirmed by the high Chl-a:Phaeo ratios. Yet, ${ }^{234} \mathrm{Th}$ activities in the surface sediment in 2008 bracket the values obtained in 2007 when Chl- $a$ and Chl-a:Phaeo ratios indicate less freshly deposited phytoplankton material.

In the northern Bay of Biscay, TEP has been shown to be a significant contributor of the pelagic POC stock (between 12\% and $54 \%$ ) and a potential contributor to the vertical flux of particulate 


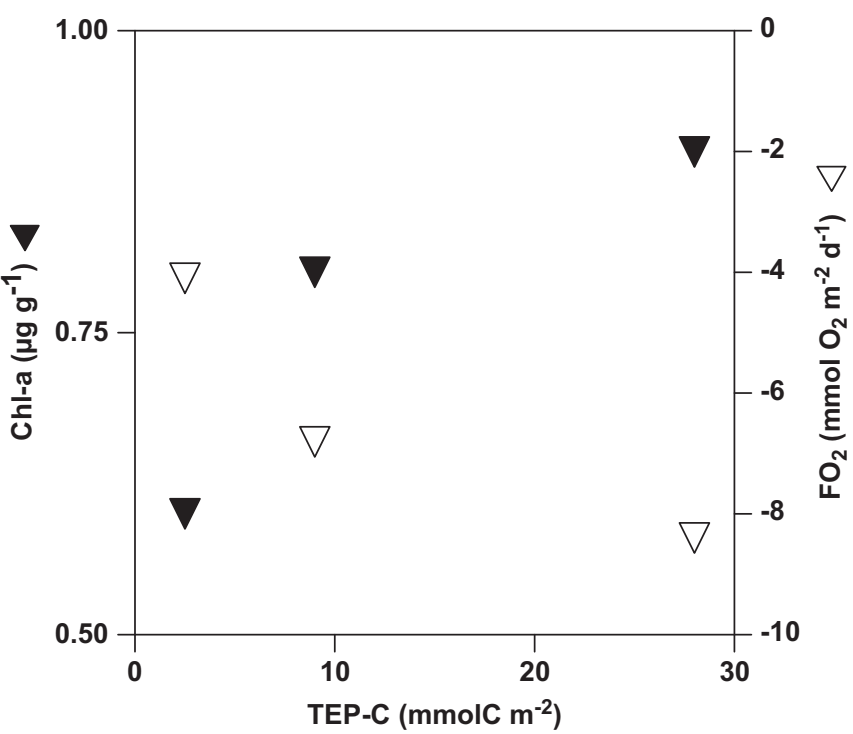

Fig. 6. Chl- $a$ concentrations $\left(\mu \mathrm{g} \mathrm{g}^{-1}\right)$ in the top $1 \mathrm{~cm}$ of the sediment and $\mathrm{FO}_{2}$ $\left(\mathrm{mmol} \mathrm{O}_{2} \mathrm{~m}^{-2} \mathrm{~d}^{-1}\right)$ versus TEP-C $\left(\mathrm{mmolC} \mathrm{m}^{-2}\right)$ at stations 5 bis, 9bis and 12 of the May 2008 cruise in the northern Bay of Biscay.

material (Harlay et al., 2009). At stations 5bis, 9bis and 12 (2008), TEP-C was sampled in the surface of sediments and concentrations were as high as $29 \mathrm{mmol} \mathrm{C} \mathrm{m}^{-2}$ which corresponds to $\sim 10 \%$ of the average pelagic integrated TEP-C at these 3 stations (Harlay, Chou, unpublished) (Fig. 6). TEP-C in the surface of the sediments was positively correlated to sediment Chl- $a$ and negatively to $\mathrm{FO}_{2}$. Hence, TEP-C export to the sediments and further diagenetic degradation could be a major sink for pelagic TEP in the area, which needs to be confirmed by further measurements.

\subsection{Fluxes: OM diagenesis}

In sediments underlying well-oxygenated bottom waters, sediment $\mathrm{O}_{2}$ consumption is the most widely used measurement of total benthic remineralization (Thamdrup and Canfield, 1996). The relationships between $\mathrm{FO}_{2}$ and the grain size fraction $<63 \mu \mathrm{m}\left(r^{2}=0.64\right)$ and Chl- $a$ content of the top $1 \mathrm{~cm}$ of the sediments $\left(r^{2}=0.43\right)$, as well as \% $\mathrm{OM}_{\mathrm{LOI}}\left(r^{2}=0.28\right)$ indicate that $\mathrm{FO}_{2}$ rates were a direct function of the availability of OM (Fig. 7). However, OC degradation processes did not show a preference towards "fresher" phytoplanktonic OM as indicated by the lack of relationship between $\mathrm{FO}_{2}$ and the Chl-a:Phaeo ratios (Fig. 7).

$\mathrm{FO}_{2}$ and $\mathrm{FNO}_{3}^{-}$were positively correlated $\left(r^{2}=0.24\right)$, with a transfer of $\mathrm{NO}_{3}^{-}$from the water column to the sediment at stations where the sediment uptake of $\mathrm{O}_{2}$ was highest, while at stations where the sediment uptake of $\mathrm{O}_{2}$ was lowest, the sediments released $\mathrm{NO}_{3}^{-}$to the water column (Fig. 7). This would indicate that at the stations where benthic OC degradation was the most intense, part of the sediment was suboxic or anoxic, leading to denitrification. Hence, with increasing OC degradation, the efflux of $\mathrm{NO}_{3}^{-}$from the sediments to the water column decreased due to removal of $\mathrm{NO}_{3}^{-}$by denitrification. At the two deep stations (2 (2006) and 6 (2008)) and 3 stations situated over the shelf of the Goban Spur (9, 9bis and 12 (2008)), the water column provided $\mathrm{NO}_{3}^{-}$for benthic denitrification, and a flux of $\mathrm{NO}_{3}^{-}$from the water column to the sediment was observed. These findings are in overall agreement with the model of Middelburg et al. (1996) for continental margin sediments in general, and with the field measurements of Balzer et al. (1998) on the continental slope and shelf at Goban Spur at depths from $300 \mathrm{~m}$ to $5200 \mathrm{~m}$.
The vast majority of biogenic silica produced in surface waters dissolves in the water column during particle sinking $(\sim 50 \%$ dissolves in the upper $100 \mathrm{~m}$ of the water column, Nelson et al. (1995)). Diatom aggregation allows a more rapid transport of biogenic silica through the water column, thereby reducing the time spent by biogenic silica in undersaturated surface waters (e.g., Alldredge et al., 1995). Yet, the positive FDSi in the northern Bay of Biscay indicates further biogenic silica dissolution in the sediments. The positive correlations between FDSi and Chl- $a$ $\left(r^{2}=0.15\right)$ as well as to the grain size $<63 \mu \mathrm{m}\left(r^{2}=0.24\right)$ (Fig. 8) could indicate that the dissolution of biogenic silica is, to some extent (given the low statistical significance of the linear regressions), controlled by the stock of biogenic silica in the sediments. Bacterial degradation in the sediments (hence $\mathrm{FO}_{2}$ ) removes the OM coating of frustules, and accelerates the rate of dissolution of biogenic silica (Smith et al., 1996; Rabouille et al., 1997; Bidle and Azam, 1999). The FDSi: $\mathrm{FO}_{2}$ ratio ranged in absolute values from 0.01 to 0.25 with an average of $0.09 \pm 0.05$. This is close to the value of 0.1 that can be predicted from the average of $\mathrm{Si}: \mathrm{C}$ ratio in marine diatoms reported by Brzezinski (1985). Yet, the low statistical significance of the correlation between $\mathrm{FDSi}$ and $\mathrm{FO}_{2}$ $\left(r^{2}=0.12\right)$ (Fig. 8) would indicate that FDSi was mainly due to the dissolution of the stock of biogenic silica in the sediments and relatively independent of OM degradation. Indeed, the dissolution of biogenic silica is mainly a purely thermodynamic process (Michalopoulos and Aller, 2004) and the regeneration of DSi and other inorganic nutrients are to a large extent decoupled (e.g., Broecker and Peng, 1982).

\subsection{Fluxes: metabolic driven dissolution of $\mathrm{CaCO}_{3}$}

OM oxidation by $\mathrm{O}_{2}$ and oxidation in oxic sediments of diffusing reduced solutes, produced by anaerobic degradation of OM, cause a build-up of $\mathrm{CO}_{2}$ and decrease of $\mathrm{pH}$ in pore waters, leading to subsequent $\mathrm{CaCO}_{3}$ undersaturation and dissolution (Emerson and Bender, 1981; Broecker and Peng, 1982; Canfield and Raiswell, 1991; Hales and Emerson, 1996, 1997; Martin and Sayles, 1996; Jahnke et al., 1997; Jahnke and Jahnke, 2000; Hales, 2003). The relationship between $\mathrm{FNO}_{3}^{-}$and $\mathrm{FO}_{2}$ indicated the occurrence of denitrification that leads to an increase of TA (Froelich et al., 1979). On the other hand, the release of $\mathrm{NO}_{3}^{-}$and $\mathrm{PO}_{4}^{3-}$ by OM degradation leads to a decrease of TA. Hence, we computed FTA* as the flux of TA corrected for the effects of denitrification and for the effect of $\mathrm{NO}_{3}^{-}$and $\mathrm{PO}_{4}^{3-}$ release from OM remineralization. Hence, FTA should only be driven by $\mathrm{CaCO}_{3}$ dissolution.

The change of TA due to aerobic remineralization $\left(\mathrm{FTA}_{\mathrm{AR}}\right)$ was computed according to:

$\mathrm{FTA}_{\mathrm{AR}}=\frac{17\left|\mathrm{FO}_{2}\right|}{138}$

We roughly evaluated denitrification as the difference between the observed $\mathrm{FNO}_{3}^{-}$and the flux of $\mathrm{NO}_{3}^{-}$expected only from $\mathrm{OM}$ remineralization evaluated from the observed $\mathrm{FO}_{2}$ and using the $\mathrm{O}_{2}: \mathrm{NO}_{3}^{-}$Redfield ratio of 138:16 (Redfield et al., 1963). The estimates of denitrification computed this way ranged from 0.0 to $1.2 \mathrm{mmol} \mathrm{m}^{-2} \mathrm{~d}^{-1}$ with an average of $0.5 \mathrm{mmol} \mathrm{m}^{-2} \mathrm{~d}^{-1}$, in agreement with the denitrification value of $0.6 \mathrm{mmol} \mathrm{m}^{-2} \mathrm{~d}^{-1}$ reported at $200 \mathrm{~m}$ by Balzer et al. (1998) in Goban Spur.

The change of TA $\left(\mathrm{FTA}_{\text {denitr }}\right)$ related to denitrification was computed as

$\mathrm{FTA}_{\text {denitr }}=\frac{16\left|\mathrm{FO}_{2}\right|}{138}-\mathrm{FNO}_{3}^{-}$

The FTA ${ }^{*}$ was computed as

$\mathrm{FTA}^{*}=\mathrm{FTA}+\mathrm{FTA}_{\mathrm{AR}}-\mathrm{FTA}_{\mathrm{denitr}}$ 

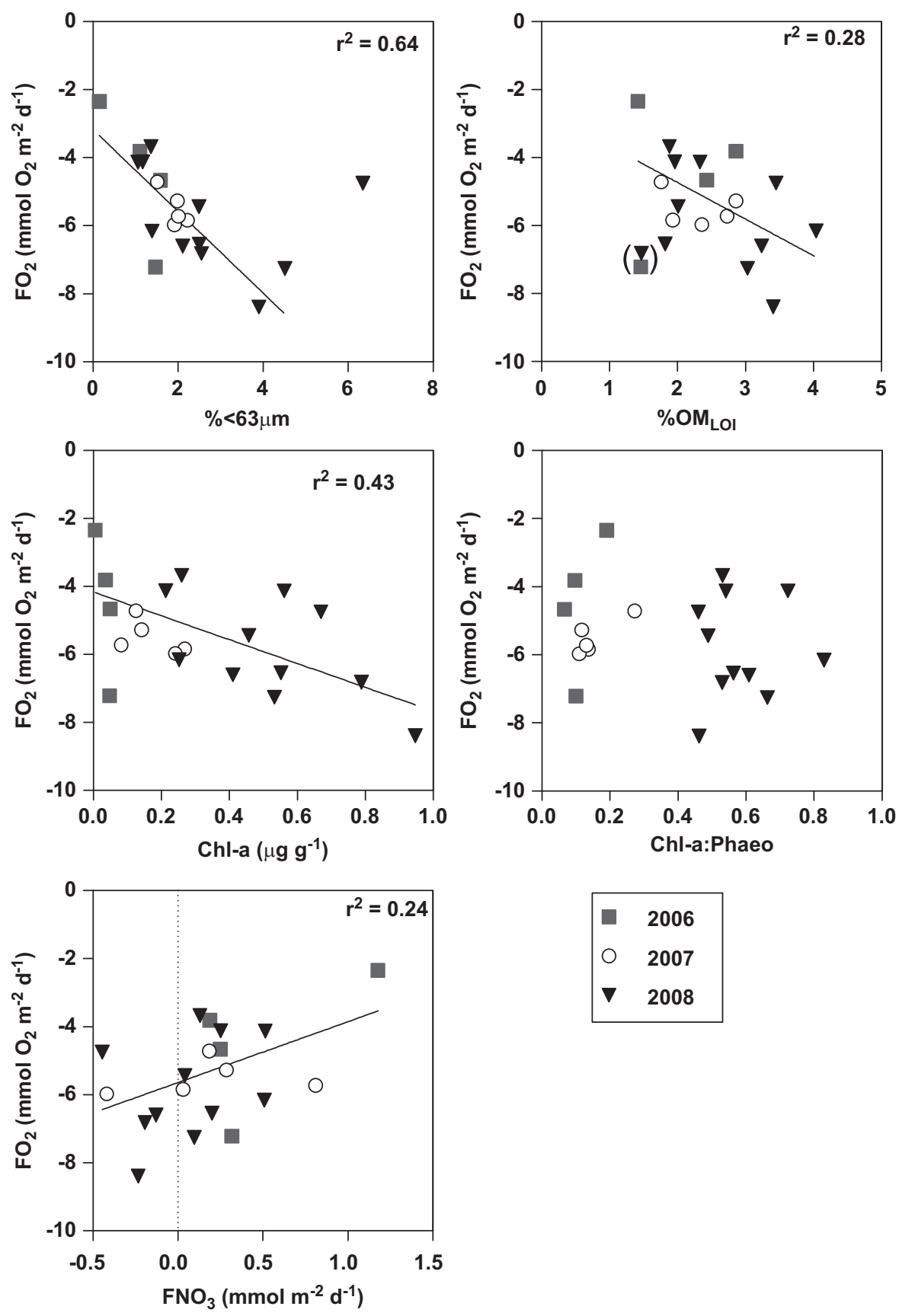

Fig. 7. $\mathrm{FO}_{2}\left(\mathrm{mmol} \mathrm{O}_{2} \mathrm{~m}^{-2} \mathrm{~d}^{-1}\right)$ versus the grain size fraction $<63 \mu \mathrm{m}(\%)$, \% $\mathrm{OM}_{\mathrm{LOI}}$ content of the top $1 \mathrm{~cm}$ of the sediment, Chl- $a$ content ( $\mu \mathrm{g} \mathrm{g}-1$ ) of the top $1 \mathrm{~cm}$ of the sediment, Chl- $a$ :Phaeo ratio of the top $1 \mathrm{~cm}$ of the sediment and $\mathrm{FNO}_{3}^{-}\left(\mathrm{mmol} \mathrm{m}^{-2} \mathrm{~d}^{-1}\right)$ in the northern Bay of Biscay, in June 2006 , May 2007 and May 2008. Solid lines represent the linear regressions. Data in brackets were excluded from the regression line.

FTA $^{*}$ represented on average $70 \%$ of the total FTA, and increased with increasing total benthic OC degradation $\left(\mathrm{FO}_{2}\right)$ (Fig. 9), indicating that metabolic driven dissolution of $\mathrm{CaCO}_{3}$ occurred at all stations. The rates of $\mathrm{CaCO}_{3}$ dissolution were evaluated as FTA $^{*} / 2$, since 2 moles of TA are produced during the dissolution of 1 mole of $\mathrm{CaCO}_{3}$ (Eq. (2)), based on the TA anomaly technique (Smith and Key, 1975) that has been frequently used to evaluate $\mathrm{CaCO}_{3}$ dissolution in the sediments (e.g., Jahnke and Jahnke, 2004). The rates of $\mathrm{CaCO}_{3}$ dissolution were relatively low (on average $\sim 0.33 \mathrm{mmol} \mathrm{m}^{-2} \mathrm{~d}^{-1}$ ). The average $\mathrm{CaCO}_{3}$ dissolution to OC oxidation ratio $\left(-\mathrm{FTA}^{*} /\left(2 \times \mathrm{FO}_{2}\right)\right)$ of $0.06 \pm 0.09$ falls in the lower range $(-0.05$ to 0.45$)$ reported by Jahnke and Jahnke (2004) in relation to metabolic driven dissolution of $\mathrm{CaCO}_{3}$ in sediments underlying bottom waters highly over-saturated with respect to $\mathrm{CaCO}_{3}$.

Fig. 10 shows the comparison of rates of benthic dissolution of $\mathrm{CaCO}_{3}$ as a function of $\mathrm{FO}_{2}$ in the northern Bay of Biscay, with data from the California continental slope (Jahnke et al., 1997), the US Mid-Atlantic continental slope (Jahnke and Jahnke, 2000), the eastern Canadian continental margin (Silverberg et al., 2000), and from a compilation in deep ocean sediments (Berelson et al., 2007). At a given $\mathrm{FO}_{2}$, rates of benthic $\mathrm{CaCO}_{3}$ dissolution in the northern Bay of Biscay were systematically lower than those reported in the US Mid-Atlantic continental slope, themselves lower than those in deep ocean sediments. This could be due to different $\Omega_{\mathrm{CAL}}$ values of the water overlying the sediments. While 

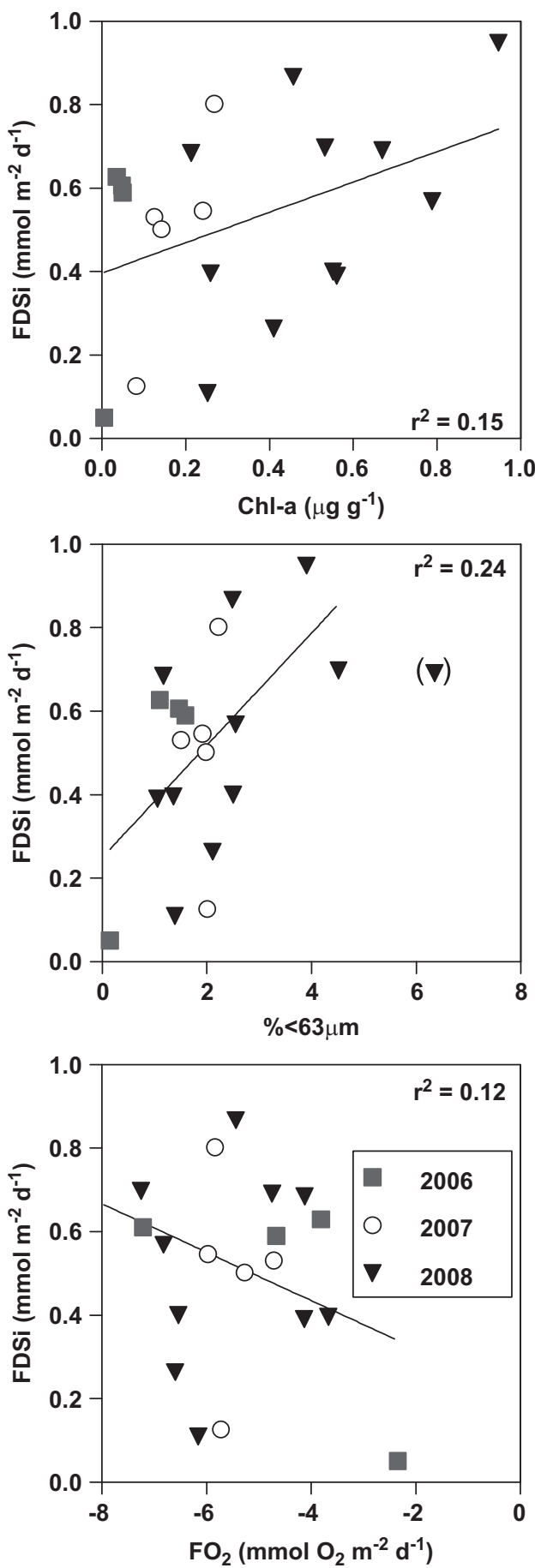

Fig. 8. FDSi ( $\left.\mathrm{mmol} \mathrm{m}^{-2} \mathrm{~d}^{-1}\right)$ versus Chl- $a$ content $\left(\mu \mathrm{g} \mathrm{g}^{-1}\right)$ of the top $1 \mathrm{~cm}$ of the sediment, grain size fraction $<63 \mu \mathrm{m}(\%)$ and versus $\mathrm{FO}_{2}\left(\mathrm{mmol} \mathrm{O}_{2} \mathrm{~m}^{-2} \mathrm{~d}^{-1}\right)$ in the northern Bay of Biscay, in June 2006, May 2007 and May 2008. Data in brackets were excluded from the regression line. Solid lines represent the linear regressions.

bottom waters overlying the sediments in the northern Bay of Biscay were highly supersaturated with respect to calcite $\left(\Omega_{\mathrm{CAL}}\right.$ averaged $3.5 \pm 0.2$, Table 1$)$, the $\Omega_{\mathrm{CAL}}$ at stations of the data compilation given by Berelson et al. (2007) averaged $1.3 \pm 0.9$ and were unavailable for the stations reported in the US Mid-Atlantic continental slope by Jahnke and Jahnke (2000) or on the eastern Canadian continental margin at $250-700 \mathrm{~m}$ depth by Silverberg et al. (2000). However, $\Omega_{\mathrm{CAL}}$ ranged between 1.4 and 2.5 at depths

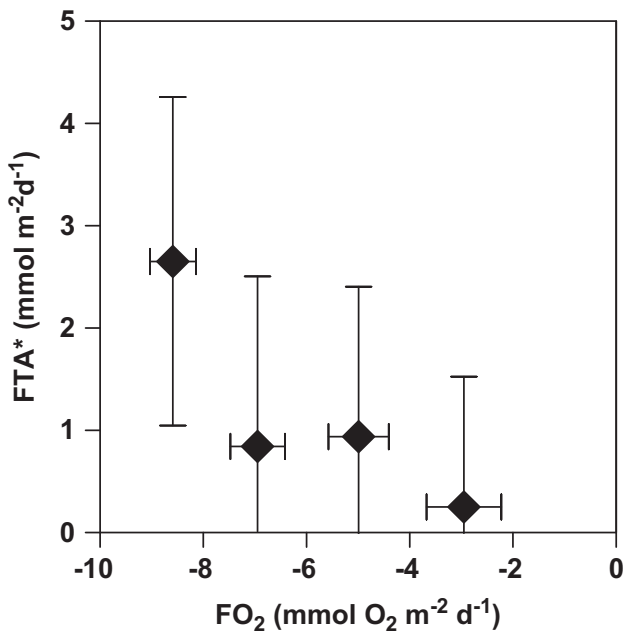

Fig. 9. $\mathrm{FTA}^{*}\left(\mathrm{mmol} \mathrm{m}^{-2} \mathrm{~d}^{-1}\right)$ versus $\mathrm{FO}_{2}\left(\mathrm{mmol} \mathrm{O}_{2} \mathrm{~m}^{-2} \mathrm{~d}^{-1}\right)$ in the northern Bay of Biscay. Data from the June 2006, May 2007 and May 2008 cruises were merged and bin-averaged per intervals of $\mathrm{FO}_{2}$ of $2 \mathrm{mmol} \mathrm{O}_{2} \mathrm{~m}^{-2} \mathrm{~d}^{-1}$.

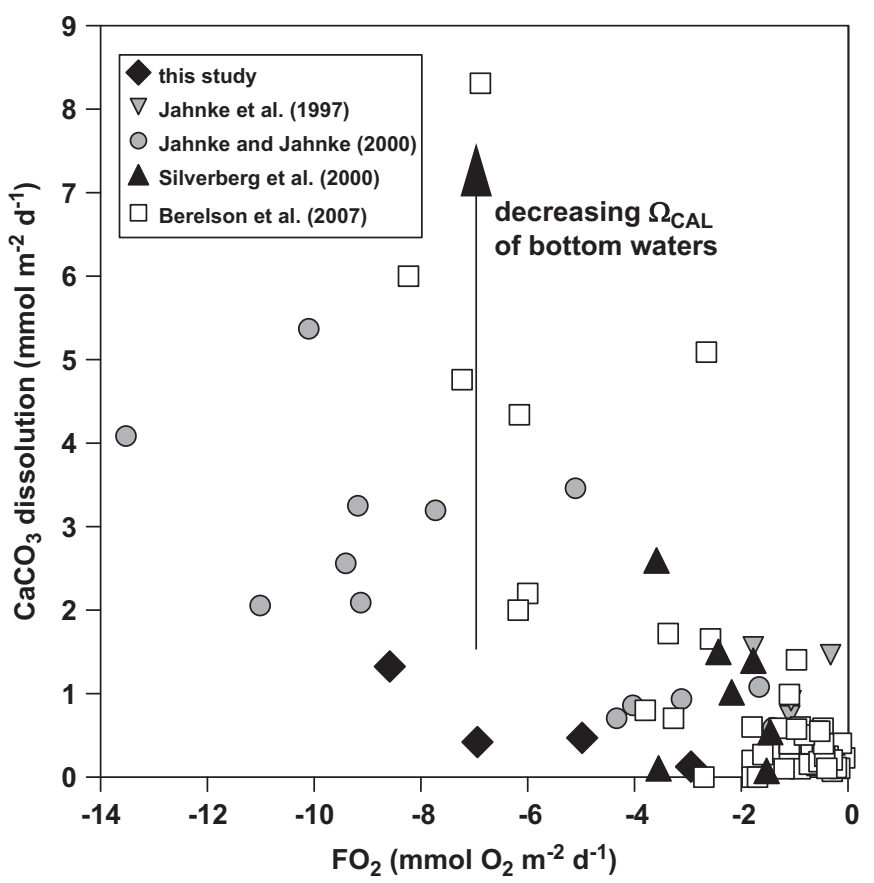

Fig. 10. Benthic $\mathrm{CaCO}_{3}$ dissolution ( $\left.\mathrm{mmol} \mathrm{m} \mathrm{m}^{-2} \mathrm{~d}^{-1}\right)$ versus $\mathrm{FO}_{2}\left(\mathrm{mmol} \mathrm{O}_{2} \mathrm{~m}^{-2} \mathrm{~d}^{-1}\right)$ in northern Bay of Biscay (this study), in the California continental slope (Jahnke et al., 1997), in the US Mid-Atlantic continental slope (Jahnke and Jahnke, 2000), on the eastern Canadian continental margin (Silverberg et al., 2000) and from a compilation in deep ocean sediments (Berelson et al., 2007).

between 605 and $2955 \mathrm{~m}$ (close to the sampling depths of the Jahnke and Jahnke (2000) study, i.e., 610 and $2930 \mathrm{~m}$ ) as extracted at $38.29^{\circ} \mathrm{N}-74.16^{\circ} \mathrm{E}$ (about $1^{\circ}$ further north from the study area of the Jahnke and Jahnke (2000) study area) from the Global Ocean Data Analysis Project (Key et al., 2004). This suggests that decreasing $\Omega_{\mathrm{CAL}}$ of the bottom waters overlying the sediments facilitates $\mathrm{CaCO}_{3}$ dissolution in addition to the $\mathrm{CO}_{2}$ built-up in pore waters due the OM degradation, in general agreement with the findings of the modeling study of Hales (2003). 


\section{Conclusions}

We acquired a dataset of water-sediment biogeochemical fluxes and sediment characteristics in the northwest European continental margin (northern Bay of Biscay) in June 2006, May 2007 and May 2008 , mostly on the continental shelf ( $<180 \mathrm{~m}$ depth), and two stations on the continental slope (520 and $680 \mathrm{~m}$ depth). Total benthic OC degradation rates as evaluated by water-sediment $\mathrm{O}_{2}$ fluxes ( -2.4 to $-8.4 \mathrm{mmol} \mathrm{O}_{2} \mathrm{~m}^{-2} \mathrm{~d}^{-1}$ ) were low due to the sandy nature (fine to coarse) of the sediment with a low \% $\mathrm{OM}_{\mathrm{LOI}}$ content ( $1 \%$ to $4 \%$ ) comparable to other observations over the open margin and continental shelf of the Bay of Biscay at similar depths (Flach and Heip, 1996; Lohse et al., 1998; Epping et al., 2002). Excess ${ }^{234}$ Th and ${ }^{210} \mathrm{~Pb}$ activity profiles indicated that sediments were influenced by strong physical mixing leading to lower deposition of OM in the sediments at the La Chapelle Bank and northward transport towards Goban Spur. The observations showed no temporal pattern between the three cruises and suggest a decoupling between surface water $\mathrm{OM}$ production and surface sediment OM deposition probably due to strong hydrodynamics in the bottom waters.

The overall average during the 3 cruises of $\mathrm{FO}_{2}$ measurements was $\sim-5.5 \pm 1.5 \mathrm{mmol} \mathrm{O}_{2} \mathrm{~m}^{-2} \mathrm{~d}^{-1}$, which represents $\sim 8 \%$ of the pelagic primary production measured during the cruises $(70 \pm 44$ mmolC $\mathrm{m}^{-2} \mathrm{~d}^{-1}$; Harlay et al., in press; Harlay, unpublished). The overall average of $\mathrm{FO}_{2}$ values represents $\sim 4 \%$ of the pelagic respiration in the aphotic zone measured during the cruises (137 \pm $60 \mathrm{mmolC} \mathrm{m}^{-2} \mathrm{~d}^{-1}$; Harlay et al., in press; Suykens and Borges, unpublished). The correlation between FTA and $\mathrm{FO}_{2}$ suggests the occurrence of metabolic driven $\mathrm{CaCO}_{3}$ dissolution in the sediments. The $\mathrm{CaCO}_{3}$ dissolution rates were lower than those reported by other studies in continental slope and deep ocean sites due to the much higher $\Omega_{\text {CAL }}$ of bottom waters overlying the continental shelf stations of the northern Bay of Biscay. Rates of $\mathrm{CaCO}_{3}$ dissolution averaged for the three cruises $\left(\sim 0.33 \pm 0.47 \mathrm{mmol} \mathrm{m}^{-2} \mathrm{~d}^{-1}\right)$ represent $\sim 1 \%$ of the pelagic calcification rates due to coccolithophores measured during the cruises $\left(\sim 34 \pm 32 \mathrm{mmol} \mathrm{m}^{-2} \mathrm{~d}^{-1}\right)$ (Harlay et al., in press; Harlay, unpublished). Visual inspection of sediments indicated that most of the PIC was related to bivalve shells (which most probably drove the bulk of benthic $\mathrm{CaCO}_{3}$ dissolution). This implies a decoupling of calcification by coccolithophores and the dissolution in the sediments of $\mathrm{CaCO}_{3}$. Hence, PIC produced by coccolithophores is either stored in the sediments or exported out of the system, but does not seem to be significantly dissolved in the sediments.

The water-sediment biogeochemical fluxes measured during this study are characteristic of a late-spring early-summer situation in the northern Bay of Biscay. At this period of the year, OM availability in superficial sediments is probably the highest owing to deposition of OM produced during the spring bloom and during summer at the shelf edge sustained by inputs of nutrients from enhanced vertical mixing by internal tides (Pingree and New, 1995). Consequently, benthic OM degradation rates are expected to be maximal in the area during late-spring early-summer. In autumn and winter, benthic OM degradation rates are expected to be lower: reduced primary production (Joint et al., 2001) leads to lower deposition of OM, and stronger near-bed currents increase sediment re-suspension (Thomsen and van Weering, 1998). As we showed, benthic $\mathrm{CaCO}_{3}$ dissolution is mainly metabolic driven (i.e., coupled to OM degradation), dissolution rates of $\mathrm{CaCO}_{3}$ in the sediments reported in this study are expected to correspond to yearly maximum; they are likely to be lowest in autumn and winter.

\section{Acknowledgments}

We are grateful to the officers and crewmembers of the R.V. Belgica and to J. Backers, J.-P. De Blauw and G. Deschepper
(Unit of the North Sea Mathematical Models) for their support during the cruises, to N. Roevros and M.-V. Commarieu for analytical assistance, and to M. Goni (Associate Editor) and one anonymous reviewer for constructive comments on a previous version of the manuscript. This work was carried out in the frame of Belgian Science Policy PEACE (Role of pelagic calcification and export of carbonate production in climate change) project (SD/CS/ 03A), and contributes to the European Integrated Project Towards an integrated marine carbon sources and sinks assessment (CARBOOCEAN, 511176). Radionuclide determinations were funded by the Action Concertee Incitative of French Research Ministry ARTTE (Application of Radionuclides as Tracers of particulate Transfer in the Environment) program. AVB and BD are research associates at the Fonds National de la Recherche Scientifique.

\section{References}

Alldredge, A.L., Passow, U., Logan, B.E., 1993. The abundance and significance of a class of large, transparent organic particles in the ocean. Deep-Sea Res. I 40 1131-1140.

Alldredge, A.L., Gotschalk, C., Passow, U., Riebesell, U., 1995. Mass aggregation of diatom blooms: insights from a mesocosm study. Deep-Sea Res. II 42, 9-28.

Aller, R.C., De Master, D.J., 1984. Estimates of particle flux and reworking at the deep-sea floor using ${ }^{234} \mathrm{Th} /{ }^{238} \mathrm{U}$ disequilibrium. Earth Planet. Sci. Lett. 67 , 308-318.

Aller, R.C., Cochran, J.K., 1976. ${ }^{234} \mathrm{Th} /{ }^{238} \mathrm{U}$ disequilibrium in near-shore sediment: particle reworking and diagenetic timescales. Earth Planet. Sci. Lett. 29, 37-50.

Balzer, W., Helder, W., Epping, E., Lohse, L., Otto, S., 1998. Benthic denitrification and nitrogen cycling at the slope and rise of the N.W. European Continental Margin (Goban Spur). Prog. Oceanogr. 42, 111-126.

Berelson, W.M., Balch, W.M. Najjar, R., Feely, R.A., Sabine, C., Lee, K., 2007. Relating estimates of $\mathrm{CaCO}_{3}$ production, export, and dissolution in the water column to measurements of $\mathrm{CaCO}_{3}$ rain into sediment traps and dissolution on the sea floor: a revised global carbonate budget. Global Biogeochem. Cycles 21 (GB1024). doi:10.1029/2006GB002803.

Berner, R.A., 1980. A rate model for organic matter decomposition during bacterial sulfate reduction in marine sediments. In: Biogeochemistry of organic matter at the sediment-water interface, Marin. Colloq. Int. CNRS No. 293, pp. 35-44.

Bidle, K.D., Azam, F., 1999. Accelerated dissolution of diatom silica by natura marine bacterial assemblages. Nature 397, 508-512.

Boudreau, B.P., 1986. Mathematics of tracer mixing in sediments: I. Spatiallydependant, diffusive mixing. Am. J. Sci. 286, 161-198.

Boudreau, B.P., Canfield, D.E., Mucci, A., 1992. Early diagenesis in a marine sapropel, Mangrove Lake, Bermuda. Limnol. Oceanogr. 37, 1738-1753.

Boudreau, B.P., Huettel, M., Forster, S., Jahnke, R.A., McLachlan, A., Middelburg, J.J., Nielsen, P., Sansone, F.J., Taghon, G.L., Van Raaphorst, W., Webster, I.T., Weslawski, J.M., Wiberg, P., Sundby, B., 2001. Permeable marine sediments: overturning an old paradigm. Eos Trans. AGU 82 (133), 135-136.

Broecker, W.S., Peng, T.H., 1982. Tracers in the Sea. Eldigio Press Lamont Doherty Geological Observatory, Palisades, NY.

Burdige, D.J., 2006. Geochemistry of Marine Sediments. Princeton University Press.

Cai, W.-J., Reimers, C., Shaw, T., 1995. Microelectrode studies of organic carbon degradation and calcite dissolution at a California Continental rise site. Geochem. Cosmochim. Acta 59, 497-511.

Canfield, D.E., Raiswell, R., 1991. Carbonate dissolution and precipitation: its relevance to fossil preservation. In: Alisson, P.A., Briggs, D.E.G. (Eds.), Taphonomy: Releasing the Data Locked in the Fossil Record: Topics in Geobiology vol. 9. Plenum Press, New York, pp. 411-453.

Carruthers, J.N., 1963. History, sand waves and near-bed currents of La Chapelle Bank. Nature 197, 942-946.

Channon, R.D., Hamilton, D., 1976. Wave and tidal current sorting of shelf sediments, southwest of England. Sedimentology 23, 17-42.

Cochran, J.K., Aller, R.C., 1979. Particle reworking in sediments from the New York Bight Apex: evidence from ${ }^{234} \mathrm{Th} /{ }^{238} \mathrm{U}$ disequilibrium. Estuarine Coastal Mar. Sci. 9, 739-747.

Dean, W.E., 1974. Determination of carbonate and organic matter in calcareous sediments and sedimentary rocks by loss on ignition: comparison with other methods. J. Sed. Petrol. 44, 242-248.

De La Rocha, C.L., Passow, U., 2007. Factors influencing the sinking of POC and the efficiency of the biological carbon pump. Deep-Sea Res. II 54, 639-658.

De Master, D.J., Mc Kee, B.A., Nittrouer, C.A., Brewster, D.C., Biscaye, P.E., 1985 Rates of sediment reworking at the HEBBLE site based on measurements of ${ }^{234} \mathrm{Th},{ }^{137} \mathrm{Cs}$ and ${ }^{210} \mathrm{~Pb}$. Mar. Geol. 66, 133-148.

Dickson, A.G., 1993. The measurement of sea water pH. Mar. Chem. 44, 131-142.

Dickson, A.G., Millero, F.J., 1987. A comparison of the equilibrium constants for the dissociation of carbonic acid in seawater media. Deep-Sea Res. 34, 1733-1743.

Dickson, A.G., Sabine, C.L., Christian, J.R., 2007. Guide to best practices for ocean $\mathrm{CO}_{2}$ measurements. PICES Special Publication 3, $191 \mathrm{pp}$. 
Emerson, S., Bender, M.L., 1981. Carbon fluxes at the sediment-water interface: calcium carbonate preservation. J. Mar. Res. 39, 139-162.

Epping, E., van der Zee, C., Soetaert, K., Helder, W., 2002. On the oxidation and burial of organic carbon in sediments of the Iberian margin and Nazare Canyon (NE Atlantic). Progr. Oceanogr. 52, 399-431.

Flach, E., Heip, C., 1996. Seasonal variations in faunal distribution and activity across the continental slope of the Goban Spur area (NE Atlantic). J. Sea Res. 36, 203-215.

Froelich, P.N., Klinkhammer, G.P., Bender, M.L., Luedtke, N.A., Heath, G.R., Cullen, D., Dauphin, P., Hammond, D., Hartman, B., Maynard, V., 1979. Early oxidation of organic matter in pelagic sediments of the eastern equatorial Atlantic; suboxic diagenesis. Geochim. Cosmochim. Acta 43, 1075-1090.

Garcia-Soto, C., Fernández, E., Pingree, R.D., Harbour, D.S., 1995. Evolution and structure of a shelf coccolitophore bloom in the Western English Channel. J. Plankton Res. 17, 2011-2036.

Gazeau, F., Smith, S., Gentili, B., Frankignoulle, M., Gattuso, J.-P., 2004. The European coastal zone: characterization and first assessment of ecosystem metabolism. Estuarine Coastal Shelf Sci. 60, 673-694.

Godoi, R.H.M., Aerts, K., Harlay, J., Kaegi, R., Chul-Un, R., Chou, L., Van Grieken, R., 2009. Organic surface coating on Coccolithophores-Emiliania huxleyi: its determination and implication in the marine carbon cycle. Microchem. J. 91, 266-271.

Gran, G., 1952. Determination of the equivalence point in potentiometric titrations of seawater with hydrochloric acid. Oceanol. Acta 5, 209-218.

Grasshoff, K., Ehrhardt, M., Kremling, K., 1983. Methods of Seawater Analysis. Verlag Chemie, Weinheim.

Hales, B., 2003. Respiration, dissolution, and the lysocline. Paleoceanography 18 , 1099. doi:10.1029/2003PA000915

Hales, B., Emerson, S.R., 1996. Calcite dissolution in sediments of the Ontong-Java Plateau: in situ measurements of porewater $\mathrm{O}_{2}$ and $\mathrm{pH}$. Global Biogeochem. Cycles 5, 529-543.

Hales, B., Emerson, S.R., 1997. Calcite dissolution in sediments of the Ceara Rise: in situ measurements of porewater $\mathrm{O}_{2}, \mathrm{pH}$ and $\mathrm{CO}_{2}(\mathrm{aq})$. Geochim. Cosmochim. Acta 61, 501-514.

Harlay, J., Borges, A.V., Zee, Van Der, Delille, C., Godoi, B., Schiettecatte, R.H.M., Roevros, L.-S., Aerts, N., Lapernat, K., Rebreanu, P.-E., Groom, L., Daro, S., Van Grieken, M.-H., Chou, L., R., 2010. Biogeochemical study of a coccolithophorid bloom in the northern Bay of Biscay (NE Atlantic Ocean) in June 2004. Progr. Oceanogr. 86, 317-336.

Harlay, J., Chou, L., De Bodt, C., Van Oostende, N., Piontek, J., Suykens, K., Engel, A., Sabbe, K. Groom, S., Delille, B., Borges, A.V. Biogeochemistry and carbon mass balance of a coccolithophore bloom in the northern Bay of Biscay (June 2006). Deep-Sea Res. I, in press, doi:10.1016/j.dsr.2010.11.005

Harlay, J., De Bodt, C., Engel, A., Jansen, S., d'Hoop, Q., Piontek, J., Van Oostende, N., Groom, S., Sabbe, K., Chou, L., 2009. In-situ abundance and size distribution of transparent exopolymer particles (TEP) in a coccolithophorid bloom in the northern Bay of Biscay (June 2006). Deep-Sea Res. I 56, 1251-1265.

Heip, C.H.R., Duineveld, G., Flach, E., Graf, G., Helder, W., Herman, P.M.J., Lavaleye, M., Middelburg, J.J., Pfannkuche, O., Soetaert, K., Soltwedel, T., de Stigter, H., Thomsen, L., Vanaverbeke, J. de Wilde, P., 2001. The role of benthic biota in sedimentary metabolism and sediment-water exchange processes in the Goban Spur area (NE Atlantic). Deep-Sea Res. II 48, 3223-3243.

Heiri, O., Lotter, A.F., Lemcke, G., 2001. Loss on ignition as a method for estimating organic and carbonate content in sediments: reproductibility and comparibility of results. J. Paleolimnol. 25, 101-110.

Herman, P.M.J., Soetaert, K., Middelburg, J.J., Heip, C., Lohse, L., Epping, E., Helder, W., Antia, A.N., Peinert, R., 2001. The seafloor as the ultimate sediment trap: using sediment properties to constrain benthic-pelagic exchange processes at the Goban Spur. Deep-Sea Res. II 48, 3245-3264.

Holligan, P.M., Fernández, E., Aiken, J., Balch, W.M., Boyd, P.W., Burkill, P.H., Finch, M., Groom, S.B., Malin, G., Muller, K., Purdie, D.A., Robinson, C., Trees, C.C., Turner, S.M., van der Wal, P., 1993. A biogeochemical study of the coccilithophore, Emiliania huxleyi in the North Atlantic. Global Biogeochem. Cycles 7, 879-900.

Howard, P.J.A., Howard, D.M., 1990. Use of organic carbon and loss-on-ignition to estimate soil organic matter in different soil types and horizons. Biol. Fertil. Soils 9, 306-310.

Hutnance, J.M., Coelho, H., Griffiths, C.R., Knight, P.J., Rees, A.P., Sinha, B., Vangriesheim, A., White, M., Chatwin, P.G., 2001. Physical structures, advection and mixing in the region of Goban spur. Deep-Sea Res. II 48, 2979-3021.

Hydes, D.J., Le Gall, A.C., Miller, A.E.J., Brockmann, U., Raabe, T., Holley, S., AlvarezSalgado, X., Antia, A., Balzer, W., Chou, L., Elskens, M., Helder, W., Joint, I., Orren, M., 2001. Supply and demand of nutrients and dissolved organic matter at and across the NW European shelf break in relation to hydrography and biogeochemical activity. Deep-Sea Res. II 48, 3023-3047.

Jahnke, R.A., Jahnke, D.B., 2000. Rates of C, N, P and Si recycling and denitrification at the US Mid-Atlantic continental slope depocenter. Deep Sea Res. I 47, $1405-1428$.

Jahnke, R.A., Jahnke, D.B., 2004. Calcium carbonate dissolution in deep-sea sediments: implications of bottom water saturation state and sediment composition. Geochem. Cosmochim. Acta 68, 47-59.

Jahnke, R.A., Craven, D.B., McCorkle, D.C., Reimers, C.E., 1997. $\mathrm{CaCO}_{3}$ dissolution in California continental margin sediments: the influence of organic matter remineralization. Geochem. Cosmochim. Acta 61, 3587-3604.

Joint, I., Wollast, R., Chou, L., Batten, S., Elskens, M., Edwards, E., Hirst, A., Brurkill, P., Groom, S., Gibb, S., Miller, A., Hydes, D., Dehairs, F., Antia, A., Barlow, R., Rees, A., Pomroy, A., Brockmann, U., Cummings, D., Lampitt, R., Loijens, M., Mantoura, F., Miller, P., Raabe, T., Alvarez-Salgado, X., Stelfox, C., Woolfenden,
J., 2001. Pelagic production at the Celtic Sea shelf break. Deep-Sea Res. II 48, 3049-3081.

Key, R.M., Kozyr, A., Sabine, C.L., Lee, K., Wanninkhof, R., Bullister, J.L., Feely, R.A., Millero, F.J., Mordy, C., Peng, T.-H., 2004. A global ocean carbon climatology: results from Global Data Analysis Project (GLODAP). Global Biogeochem. Cycles 18 (GB4031). doi:10.1029/2004GB002247.

Knap, A.H., Michaels, A.E., Close, A., Ducklow, H.W., Dickson, A.G., 1996. Protocols for the Joint Global Ocean Flux Study (JGOFS) core measurements. JGOFS Reports, 19, Bergen, Norway, UNESCO.

Koide, M., Bruland, K.W., Goldberg, E.D., 1973. Th-228/Th-232 and Pb-210 geochronologies in marine and lake sediments. Geochim. Cosmochim. Acta 37, 1171-1183.

Lampitt, R.S., 1985. Evidence for the seasonal deposition of detritus to the deepsea floor [Porcupine Bight, NE Atlantic] and its subsequent resuspension. Deep-Sea Res. 32, 885-897.

Leckie, D.A., 1988. Wave-formed, coarse-graines ripples and their relationship to hummocky cross-stratification. J. Sed. Petrol. 58, 607-622.

Lewis, E., Wallace, D.W.R., 1998. CO2SYS-Program developed for the $\mathrm{CO}_{2}$ system calculations. Report ORNL/CDIAC-105, Carbon Dioxide Information Analysis Center.

Lohse, L., Helder, W., Epping, E.H.G., Balzer, W., 1998. Recycling of organic matter along a shelf-slope transect across the N.W. European Continental Margin (Goban Spur). Progr. Oceanogr. 42, 77-110.

Martin, W.R., Sayles, F.L., 1996. $\mathrm{CaCO}_{3}$ dissolution in sediments of the Ceara Rise, western equatorial Atlantic. Geochim. Cosmochim. Acta 60, 243-263.

Mehrbach, C., Culberson, C.H., Hawley, J.E., Pytkowicz, R.M., 1973. Measurement of the apparent dissociation constants of carbonic acid in seawater at atmospheric pressure. Limnol. Oceanogr. 18, 897

Michalopoulos, P., Aller, R.C., 2004. Early diagenesis of biogenic silica in the Amazon delta: alteration, authigenic clay formation, and storage. Geochim. Cosmochim. Acta 68 (5), 1061-1085.

Middelburg, J.J., Soetaert, K., Herman, P.M.J., Heip, C.H.R., 1996. Denitrification in marine sediments: a model study. Global Biogeochem. Cycles 10, 661-673.

Milliman, J.D., 1993. Production and accumulation of calcium carbonate in the ocean: budget of a nonsteady state. Global Biogeochem. Cycles 7, 927-957.

Mucci, A., 1983. The solubility of calcite and aragonite in seawater at various salinities, temperatures, and one atmosphere total pressure. Am. J. Sci. 283, 781-799.

Nelson, D.M., Treguer, P., Brzezinski, M.A., Leyneart, A., Queguiner, B., 1995. Production and dissolution of biogenic silica in the ocean: revised global estimates, comparison with regional date and relationship to biogenic sedimentation. Global Biogeochem. Cycles 9, 359-372.

Passow, U., 2002. Transparent exopolymer particles (TEP) in aquatic environments. Prog. Oceanogr. 55, 287-333.

Passow, U., Alldredge, A.L., 1995. A dye-binding assay for the spectrophotometric measurement of transparent exopolymer particles (TEP). Limnol. Oceanogr. 40, 1326-1335.

Pingree, R.D., Le Cann, B., 1989. Celtic and Armorican slope and shelf residual currents. Prog. Oceanogr. 23, 303-339.

Pingree, R.D., New, A.L., 1995. Structure, seasonal development and sunglint spatial coherence of the internal tide on the Celtic and Armorican shelves and in the Bay of Biscay. Deep-Sea Res. I 42, 245-284.

Pingree, R.D., Le Cann, B., 1990. Structure, strength and seasonality of the slope currents in the Bay of Biscay region. J. Mar. Biol. Assoc. UK 70, 857-885.

Pingree, R.D., Garcia-Soto, C., Sinha, B., 1999. Position and structure of the Subtropical/Azores Front region from combined Lagrangian and remote sensing (IR/altimeter/SeaWiFS) measurements. J. Mar. Biol. Assoc. UK 79, 769-792.

Rabouille, C., Gaillard, J.-F., Tréguer, P., Vincendeau, M.-A., 1997. Biogenic silica recycling in surficial sediments across the Polar Front of the Southern Ocean (Indian Sector). Deep-Sea Res. II 44, 1151-1176.

Redfield, A.C., Ketchum, B.H., Richards, F.A., 1963. The influence of organisms on the composition of sea-water. In: Hill, M.N. (Ed.), The Sea, vol. 2. The Composition of Seawater. Wiley, New York, pp. 26-87.

Reimers, C.E., Stecher III, H.A., Taghon, G.L., Fuller, C.M., Huettel, M., Rusch, A., Ryckelynck, N., Wild, C., 2004. In situ measurements of advective solute transport in permeable shelf sands. Cont. Shelf Res. 24, 183-201.

Reynaud, J.-Y., Tessier, B., Berné, S., Chamley, H., Debatist, M., 1999. Tide and wave dynamics on a sand bank from the deep shelf of the Western Channel approaches. Mar. Geol. 161, 339-359.

Riley, J.P., Tongudai, M., 1967. The major cation/chlorinity ratios in sea water. Chem. Geol. 2, 263-269.

Robbins, J.A., Edgington, D.N., 1975. Determination of recent sedimentation rates in Lake Michigan using ${ }^{210} \mathrm{~Pb}$ and ${ }^{137} \mathrm{Cs}$. Geochim. Cosmochim. Acta 39, 285-304.

Rusch, A., Huettel, M., Wild, C., Reimers, C.E., 2006. Benthic oxygen consumption and organic matter turnover in organic-poor, permeable shelf sands. Aquat. Geochem. 12, 1-19.

Santisteban, J.I., Mediavilla, R., López-Pamo, E., Dabrio, C.J., Zapata, M.B.R., García, M.J.G., Castaño, S., Martínez-Alfaro, P.E., 2004. Loss in ignition: a qualitative or quantitative method for organic matter and carbonate mineral content in sediments? J. Paleolimnol. 32, 287-299.

Schmidt, S., van Weering, T.C.E., Reyss, J.-L., van Beek, P., 2002a. Seasonal deposition and reworking at the sediment-water interface on the northwestern Iberian Margin. Progr. Oceanogr. 52, 331-348. 
Schmidt, S., Andersen, V., Belviso, S., Marty, J.-C., 2002b. Strong seasonality in particle dynamics of north-western Mediterranean surface waters as revealed by ${ }^{234} \mathrm{Th} /{ }^{238} \mathrm{U}$. Deep-Sea Res. I 49, 1507-1518.

Schmidt, S., Gonzalez, J.-L., Lecroart, P., Tronczyński, J., Billy, I., Jouanneau, J.-M., 2007. Bioturbation at the water-sediment interface of the Thau Lagoon: impact of shellfish farming. Aquat. Living Resour. 20, 163-169.

Schmidt, S., Howa, H., Mouret, A., Lombard, F., Anschutz, P., Labeyrie, L., 2009. Particle fluxes and recent sediment accumulation on the Aquitanian margin of Bay of Biscay. Cont. Shelf Res. 29, 1044-1052.

Sharples, J., Tweddle, J.F., Green, J.A.M., Palmer, M.R., Kim, Y.-N., Hickman, A.E. Holligan, P.M., Moore, C.M., Rippeth, T.P., Simpson, J.H., Krivtsov, V., 2007. Spring-neap modulation of internal tide mixing and vertical nitrate fluxes at a shelf edge in summer. Limnol. Oceanogr. 52, 1735-1747.

Sharples, J., Moore, C.M., Hickman, A.E., Holligan, P.M., Tweddle, J.F., Palmer, M.R. Simpson, J.H., 2009. Internal tidal mixing as a control on continental margin ecosystems. Geophys. Res. Lett. 36, L23603. doi:10.1029/2009GL040683.

Silverberg, N., Sundby, B., Mucci, A., Zhong, S., Arakaki, T., Hall, P., Landén, A Tengberg, A., 2000. Remineralization of organic carbon in eastern Canadian continental margin sediments. Deep-Sea Res. II 47, 699-731.

Smith, C.R., Hoover, D.J., Doan, S.E., Pope, R.H., De Master, D.J., Dobbs, F.C., Altabet, M.A., 1996. Phytodetritus at the abyssal seafloor across $10^{\circ}$ of latitude in the central equatorial Pacific. Deep-Sea Res. 43, 1309-1338.

Smith, S.V., Key, G.S., 1975. Carbon dioxide and metabolism in marine environments. Limnol. Oceanogr. 20, 493-495.

Soetaert, K., Herman, P.M.J., Middelburg, J.J., 1996. A model of early diagenetic processes from the shelf to abyssal depths. Geochim. Cosmochim. Acta 60, 1019-1040.
Sutherland, R.A., 1998. Loss-on-ignition estimates of organic matter and relationships to organic carbon in fluvial bed sediments. Hydrobiologia 389, 153-167.

Suykens, K., Delille, B., Chou, L., De Bodt, C., Harlay, J., Borges, A.V., 2010. Dissolved inorganic carbon dynamics and air-sea carbon dioxide fluxes during coccolithophore blooms in the Northwest European continental margin (northern Bay of Biscay). Global Biogeochem. Cycles 24 (GB3022). doi:10.1029/ 2009GB003730.

Thamdrup, B., Canfield, D.E., 1996. Pathways of carbon oxidation in continental margin sediments off central Chile. Limnol. Oceanogr. 41, 1629-1650.

Thomsen, L., van Weering, T.C.E., 1998. Spatial and temporal variability of particulate matter in the benthic boundary layer at the N.W. European Continental Margin (Goban Spur). Prog. Oceanogr. 42, 61-76.

van Weering, T.C.E., De Stigter, H.C., Balzer, W., Epping, E.H.G., Graf, G., Hall, I.R. Helder, W., Khripounoff, A., Lohse, L., McCave, I.N., Thomson, L., Vangriesheim, A., 2001. Benthic dynamics and carbon fluxes on the NW European continental margin. Deep-Sea Res. II 48, 3191-3221.

Walsh. J.., 1991. Importance of continental margins in the marine biogeochemical cycling of carbon and nitrogen. Nature 350, 53-55.

Wollast, R., Chou, L., 2001. The carbon cycle at the ocean margin in the northern Gulf of Biscay. Deep-Sea Res. II 48, 3265-3293.

Yentsch, C.S., Menzel, D.W., 1963. A method for determination of chlorophyll and phaeophytin by fluorescence. Deep-Sea Res. 10, 221-231.

Zaragosi, S., Eynaud, F., Pujol, C., Auret, G.A., Turon, J.-L., Garlan, T., 2001. Initiation of the European deglaciation as recorded in the northwestern Bay of Biscay slope environments (Meriadzek Terrace and Trevelyan Escarpment): a multiproxy approach. Earth Planet. Sci. Lett. 188, 493-507. 